\title{
Phytopathology"
}

\section{Vitis Methods to Understand and Develop Strategies for Diagnosis and Sustainable Control of Grapevine Trunk Diseases}

\author{
P. Reis, ${ }^{1}$ R. Pierron, ${ }^{2}$ P. Larignon, ${ }^{3}$ P. Lecomte, ${ }^{4}$ E. Abou-Mansour, ${ }^{5}$ S. Farine, ${ }^{6}$ C. Bertsch, ${ }^{6}$ A. Jacques, ${ }^{7}$ P. Trotel-Aziz, ${ }^{8}$ \\ C. Rego, ${ }^{1}$ and F. Fontaine ${ }^{8, \dagger}$
}

${ }^{1}$ Linking Landscape, Environment, Agriculture and Food, Instituto Superior de Agronomia, Universidade de Lisboa, Tapada da Ajuda, $1349-017$ Lisboa, Portugal

${ }^{2}$ Department of Plant Pathology, Stellenbosch University, Private Bag X1, Matieland 7602, South Africa

${ }^{3}$ Institut Français de la Vigne et du Vin Pôle Rhône-Méditerranée, France, 7 avenue Cazeaux, Rodilhan 30230, France

${ }^{4}$ UMR Santé et agroécologie du vignoble, INRA-Bordeaux Sciences Agro, 71 avenue Edouard Bourlaux, CS 20032, 33882 Villenave d'Ornon, France

${ }^{5}$ Université de Fribourg, Département de Biologie, rue du Musée 10, 1700 Fribourg, Switzerland

${ }^{6}$ Université Haute-Alsace, Laboratoire Vigne Biotechnologie et Environnement EA 3991, 33 rue Herrlisheim, 68008 Colmar cedex, France

${ }^{7}$ Ecole d'Ingénieurs de Purpan, 75 voie du Toec, BP57611, 31076 Toulouse cedex 3, France

${ }^{8}$ SFR Condorcet FR CNRS 3417, Université de Reims Champagne-Ardenne, RIBP EA 4707, BP 1039, 51687 Reims Cedex 2 , France

Accepted for publication 7 March 2019.

\begin{abstract}
Vitis vinifera is affected by many diseases every year, depending on causal agents, susceptibility of cultivars, and climate region. Some are caused by a single agent, such as gray mold caused by Botrytis cinerea or powdery mildew caused by Erysiphe necator. Others result from the actions of a complex of pathogens such as grapevine trunk diseases (GTDs). GTDs are presently among the most devastating diseases in viticulture worldwide because both the economic losses and the long-term sustainability of vineyards are strongly affected. The complexity of GTDs results from the diversity of associated fungi, the undetermined period of latency within the vine (asymptomatic status), the erratic foliar symptom expression from one year to the next, and, probably correlated with all of these points, the lack of efficient strategies to control them. Distinct methods can be beneficial to improve our knowledge of GTDs. In vitro bioassays with cell suspensions, calli, foliar discs, full leaves, or plantlets, and in vivo natural bioassays with cuttings, grafted plants in the greenhouse, or artificially infected ones in the vineyard, can be applied by using progressive integrative levels of in vitro and in vivo, depending on the information searched. In this review, the methods available to understand GTDs are described in terms of experimental procedures, main obtained results, and deliverable prospects. The advantages and disadvantages of each model are also discussed.
\end{abstract}

Keywords: Botryosphaeria dieback, callus, cell suspension, cutting, Diplodia seriata, esca disease, Eutypa dieback, Eutypa lata, grafted plant, Neofusicoccum parvum, Phaeoacremonium minimum, Phaeomoniella chlamydospora, plantlet, pruning wound, vineyard.

Vitis vinifera $\mathrm{L}$. is one of the oldest cultivated crops, with important human nutritional and health benefits and of great economic impact worldwide. However, it is susceptible to attack by a diverse range of phytopathogens that compromise the productivity and longevity of

${ }^{\dagger}$ Corresponding author: F. Fontaine; E-mail: florence.fontaine@univ-reims.fr

Funding: This work was conducted within European Cooperation in Science and Technology COST Action FA1303 "Sustainable control of grapevine trunk diseases". COST Action is supported by the EU RTD Framework programme and ESF provides the COST Office through an EC contract.

The author(s) declare no conflict of interest.

(C) 2019 The American Phytopathological Society the vines, affect rooting capacity, plant architecture, and vitality and, ultimately, resulting in mortality (Ferreira et al. 2004). Among these diseases, grapevine trunk diseases (GTDs) are currently considered to be the most important challenge for viticulture (Bertsch et al. 2013; De la Fuente et al. 2016). These destructive diseases cause severe damage every year, and they are of rapidly growing concern in all wine-producing countries of the world. GTDs harm the sustainability of winemaking heritage because the causal agents attack the perennial organs, ultimately killing the vines in either the short or long term. Esca disease, which is defined as a disease complex associated with vascular and wood decay pathogens, and Eutypa and Botryosphaeria diebacks are the main decay diseases, while Petri disease, black foot disease, and Phomopsis dieback are seen mostly in young vineyards. 
Most GTD pathogens colonize the perennial woody tissues of vines, infecting via pruning wounds (Rolshausen et al. 2010). Wood symptoms consist of brown wood streaking, internal necrotic lesions, brown stripes in the outer xylem, or perennial cankers, with symptoms differing according to the disease (Mondello et al. 2018; Mugnai et al. 1999). Associated with symptoms in the wood, foliar symptoms may appear, although their expression is not systematic and can be discontinuous from one year to the next due to environmental, climatic, and cultural changes (Murolo and Romanazzi 2014; van Niekerk et al. 2011). For Eutypa dieback, foliar symptoms are stunted shoots and small, chlorotic leaves with cup-shaped deformation appearing early in the growing season (Mondello et al. 2018). Symptoms of the esca disease complex are visible in summer, when leaf stripe symptoms can be seen on the entire plant as well as a sudden wilting of part or all of the plant (i.e., apoplexy) (Gramaje et al. 2018; Lecomte et al. 2012; Mondello et al. 2018; Mugnai et al. 1999). Minute black spots called "black measles" are frequently seen on the berries. The first symptoms of Botryosphaeria dieback are visible from budburst in spring and consist of dead spurs or buds associated with stunted or delayed growth, as is sometimes observed for Eutypa dieback. According to some authors, a severe form similar to esca apoplexy can also appear (Larignon et al. 2001). Foliar symptoms, when present, include chlorosis and discoloration similar to esca.

Eutypa dieback is now known to be associated with 24 species in the family Diatrypaceae, of which the most virulent and common is Eutypa lata (Carter 1991; Gramaje et al. 2018; Mondello et al. 2018). Typical foliar symptoms of Eutypa dieback have been reproduced following artificial infection with E. lata (Camps et al. 2010; Péros and Berger 1994; Petzoldt et al. 1981; Sosnowski et al. 2007). Pioneer fungi of esca disease are Phaeomoniella chlamydospora and species of the genus Phaeoacremonium, with Phaeoacremonium minimum being the most prevalent and virulent (Gramaje et al. 2018). To a lesser extent, other fungi belonging to the genera Fomitiporia and Stereum are also associated with esca disease (Cloete et al. 2015). At least 26 botryosphaeriaceaous taxa are associated with GTDs, especially Botryosphaeria dieback (Gramaje et al. 2018; Úrbez-Torres 2011), but the most frequently isolated and virulent are from the genera Diplodia, Lasiodiplodia, Neofusicoccum, and Neoscytalidium. All of these GTD pathogens can produce phytotoxins (Abou-Mansour et al. 2015; Andolfi et al. 2011; Cimmino et al. 2017), which are translocated to the leaves via the xylem and may be responsible for the emergence of foliar symptoms (Mugnai et al. 1999).

Several hypotheses have been proposed relating to the role of the various pathogens in symptom expression, their lifestyle, the flexibility of their aggressiveness according to their associated metabolites, the molecular dialog between the grapevine and the microbiome, and their role in the development of occlusions or other hydraulic consequences. The complexity of GTDs could be explained by the diversity of fungi and the metabolites they produce (toxins and exopolysaccharides), especially their contribution to the expression of several symptoms associated with GTDs. These factors, together with the incomplete knowledge about the influence of environmental factors on the development of GTD symptoms, have resulted in a lack of information on the connection between the actors conditioning GTDs expression. In some cases, Koch's postulates are needed to validate the role of GTD pathogens.

Over the years, several methods have been developed and transferred from the laboratory to the field to answer questions about GTDs and test various hypotheses. In this review, the methods currently used and their respective purpose are described (Table 1). An overview of each method will be provided by describing the protocol used, and their values, limitations, advantages, and disadvantages will be described and discussed. The main information that each method can provide is also discussed.

\section{CELL SUSPENSION AND CALLUS CULTURES TO DETECT MOLECULES ASSOCIATED WITH PHYTOTOXICITY OR AGGRESSIVENESS OF GTD PATHOGENS AND TO DESCRIBE EARLY HOST SIGNALING EVENTS}

The causal agents of GTDs can produce several metabolites, some of which might be considered to be toxins (Abou-Mansour et al. 2015; Evidente et al. 2011). They are translocated to the leaves via the xylem and are suspected of being involved in the expression of foliar symptoms (Mugnai et al. 1999). A great diversity of pathogen-derived biochemicals is currently under study to decipher their role in GTD foliar symptom expression, such as secreted proteins (Bénard-Gellon et al. 2015), exopolysaccharides (Bruno and Sparapano 2006), and secondary metabolites (Abou-Mansour et al. 2004). Cell suspensions and calli, composed of undifferentiated cells, can be useful to easily and quickly test the toxicity of these compounds and relate them to their roles in pathogen virulence (Fig. 1; Table 2).

The procedures with cell suspensions and calli to screen toxic compounds are as follows and described according to RamírezSuero et al. (2014) for calli and Stempien at al. (2017) for cell suspensions. Calli of cultivar Chardonnay clone 96 were obtained from anthers, as described by Perrin et al. (2004). All calli were subcultured every 3 weeks on MPM1 medium and maintained in the dark at $25 \pm 0.5^{\circ} \mathrm{C}$ with $70 \pm 10 \%$ relative humidity. For each test, 30 yellowish white calli, with a diameter of $10 \pm 2 \mathrm{~mm}$, were used. The toxicity test can consist of a global approach by using the liquid culture medium filtrate of fungi, or a targeted approach in which the purified molecules were used. When using the culture medium filtrate of fungi, the supernatant is recovered and filtered through membranes with a $0.20-\mu \mathrm{m}$ pore size to eliminate spores and to sterilize the solution. After optimization of the calli culture conditions, the culture medium filtrate from each fungus was incorporated into the MPM1 calli medium and corresponded to a $40 \%$ (vol/vol) final concentration, which was established as the sublethal concentration (Ramírez-Suero et al. 2014). For the purified molecules, the appropriate concentration of the tested molecule was incorporated into the MPM1 calli medium. For example, to evaluate the effects of protein samples on calli, a final

TABLE 1

Set of methods to be reviewed and their use

\begin{tabular}{llcl}
\hline Cell suspension and callus cultures & \multicolumn{1}{c}{$\begin{array}{c}\text { Plantlet and foliar } \\
\text { explants }\end{array}$} & $\begin{array}{c}\text { Entire plant assay with } \\
\text { artificial inoculation }\end{array}$ & $\begin{array}{c}\text { Field assays for validation } \\
\text { through artificial inoculation }\end{array}$ \\
\hline Necrosis development & Nexin effects & Foliar symptom expression & $\begin{array}{c}\text { Fungal colonization and disease } \\
\text { expression }\end{array}$ \\
\hline Growth inhibition of callus & Physiological effect & Microscopy analysis & Necrosis development \\
\hline Molecular effects & Molecular effect & Molecular effect & Molecular effect \\
\hline
\end{tabular}


concentration of proteins at $300 \mu \mathrm{g} \mathrm{ml}^{-1}$ was added. This protein concentration was estimated on the basis of the protein concentration present in the previous tests performed with culture medium filtrate from the fungus at $40 \%$ ( vol/vol). To evaluate the toxic effects of mellein, a purified toxin isolated from the liquid culture media of Diplodia seriata was added at different concentrations (25, 200 , and $500 \mu \mathrm{g} \mathrm{ml}^{-1}$ ) to the MPM1 calli medium. Mellein added to the MPM1 media at 25 and $200 \mu \mathrm{g} \mathrm{ml}^{-1}$ did not induce any necrosis at 1,3 , and 6 days. However, at $500 \mu \mathrm{g} \mathrm{m}^{-1}$, slight and partial necrosis was observed on calli after 6 days of contact. Three-weekold $V$. vinifera 'Chardonnay' calli were then subcultured onto the amended MPM1 media and incubated at $25^{\circ} \mathrm{C}$ in the dark. Toxicity of the secreted extracellular compounds or the purified molecules was assessed visually by the appearance of necrosis on the calli after $0,1,3$, and 6 days and by analysis of defense gene expression (Bénard-Gellon et al. 2015; Ramírez-Suero et al. 2014). Five calli (from five different Petri dishes) were collected for each condition and at each time point ( $0,1,2$, and 6 days).

To investigate early signaling events such as ion fluxes and reactive oxygen species production, cell suspensions were used. Cell cultures were obtained from nonembryogenic callus. Suspension cell cultures of cultivar Gewurztraminer were maintained in adapted Murashige and Skoog (MS) liquid medium in the dark and at $25 \pm 0.5^{\circ} \mathrm{C}$ on an orbital shaker at $120 \mathrm{rpm}$. Cells were subcultured every week by transferring $20 \mathrm{ml}$ of the cell culture into $80 \mathrm{ml}$ of fresh medium. Six days after subculture, cells were treated with fungal culture filtrates or purified molecules. This method can be used to study defense reactions such as production of phytoalexins and phytohormones, expression of defense genes, and programmed cell death (Stempien et al. 2017).

In vitro callus bioassays were used to understand the inhibitory effect of toxins from Phaeoacremonium angustius or Phaeomoniella chlamydospora in callus growth (Abou-Mansour et al. 2004; Santos et al. 2005). This model was also used to study the virulence of $P$. minimum and $P$. chlamydospora strains (Santos et al. 2005)

FIGURE 1

Callus assay for Vitis vinifera to test pathogen aggressiveness. A, Callus medium in an Erlenmeyer flask and supernatant of pathogens in a tube to test toxicity of the extracellular compounds and proteins. B,

Three-week-old calli. C, Coculture of callus with extracellular compounds or proteins incorporated in the culture medium. D, Calli sub-

cultured for 6 days in Petri dishes with malt medium proteins (D1)

native protein fractions produced by Neofusicoccum parvum isolate Bourgogne S-116 (D2) and Diplodia seriata isolate 98.1 (D3) after 6 days of contact. evaluated by their effect on the growth of calli and the severity of induced necrosis. For example, Bruno and Sparapano (2006) observed various degrees of necrosis in $V$. vinifera 'Italia' and 'Mathilde' calli grown with extracellular compounds from three different esca-associated fungi ( $P$. chlamydospora, $P$. minimum, and Fomitiporia mediterranea), suggesting a different level of susceptibility for these two cultivars. Callus methods have also been used to quickly assess the toxicity of purified $(R)$-mellein (details on chemical structures are provided by Andolfi et al. [2011] and Abou-Mansour et al. [2015]), a characteristic toxin present in the extracellular compounds of taxa in Botryosphaeriaceae (Bénard-Gellon et al. 2015; Ramírez-Suero et al. 2014). Callus methods are also often used to study expression of defense genes in different diseases or to study the effects of elicitors (Wielgoss and Kortekamp 2006).

\section{PLANTLETS AND FOLIAR EXPLANTS TO DECIPHER THE MOLECULAR AND PHYSIOLOGICAL EFFECTS OF MOLECULES ASSOCIATED WITH AGGRESSIVENESS PRODUCED BY GTD PATHOGENS AT DIFFERENT PLANT INTEGRATIVE LEVELS}

Cell suspensions and calli are useful tools to prescreen the toxicity of some GTD fungal metabolites by observing their ability to cause necrosis or modulate plant defense responses, especially during the early stages of the diseases. Nevertheless, these preliminary toxicity bioassays are far from the whole-plant organizational level needed to ascertain any final conclusions. Following this first screening, the use of in vitro plantlets (i.e., plants with root system, herbaceous stems, and leaves without reproductive organs and growing in a sterile tube) or foliar explants (i.e., leaf-disc or full leaf) can be used to decipher the molecular and physiological effects of the molecules associated with pathogen aggressiveness on plant responses at different plant organizational levels (Table 2). Among plant responses, research focused on the balance between
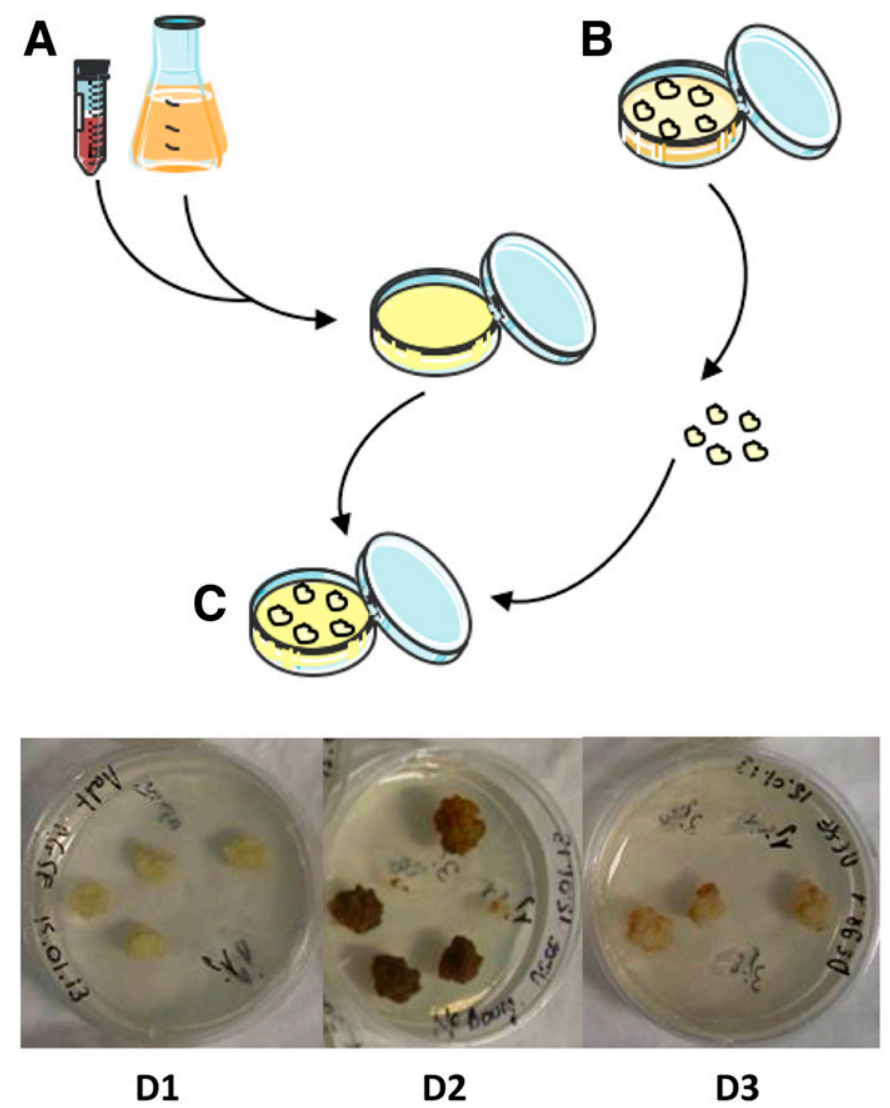
the primary metabolism and the defense responses, especially the detoxification processes, including the metabolization of phytotoxins, their cell sequestration, and their transport within the whole plant.
Leaf methods to evaluate the toxic nature of secreted compounds: From leaf discs to full leaves. Early-stage investigations of phytotoxic substances produced in cultures of microorganisms invariably demand the use of complementary bioassays to

TABLE 2

Synthesis of the Vitis methods available to understand grapevine trunk diseases

\begin{tabular}{|c|c|c|c|}
\hline Methods, diseases, pathogens & Treatments & Parameter studied & References \\
\hline \multicolumn{4}{|l|}{ Cell suspension } \\
\hline $\begin{array}{l}\text { Neofusicoccum parvum, } \\
\text { Diplodia seriata }\end{array}$ & $\begin{array}{l}\text { Coculture of the secreted } \\
\text { secondary metabolites and the } \\
\text { cells }\end{array}$ & $\begin{array}{l}\text { Phytoalexins and } \\
\text { phytohormones production, } \\
\text { defense gene expression, } \\
\text { programmed cell death }\end{array}$ & Stempien et al. 2017 \\
\hline \multicolumn{4}{|l|}{ Callus } \\
\hline N. parvum, D. seriata & $\begin{array}{l}\text { Coculture of the secreted } \\
\text { secondary metabolites and the } \\
\text { calli }\end{array}$ & $\begin{array}{l}\text { Visual observation of necrosis, } \\
\text { defense gene expression }\end{array}$ & $\begin{array}{l}\text { Abou-Mansour et al. } 2015, \\
\text { Ramírez-Suero et al. } 2014\end{array}$ \\
\hline $\begin{array}{l}\text { Phaeomoniella } \\
\text { chlamydospore, } \\
\text { Phaeoacremonium } \\
\text { minimum, Fomitiporia } \\
\text { mediteranea }\end{array}$ & Inoculation of the calli & $\begin{array}{l}\text { Evaluation of the host-pathogen } \\
\text { interactions }\end{array}$ & Bénard-Gellon et al. 2015 \\
\hline P. angustiu, $P$. chlamydospora & Inoculation of the calli & $\begin{array}{l}\text { Fungal growth rates, } \\
\text { malondialdehyde production, } \\
\text { chlorophyll content and } \\
\text { fluorescence }\end{array}$ & $\begin{array}{l}\text { Sparapano et al. 2001, Santos } \\
\text { et al. } 2005\end{array}$ \\
\hline $\begin{array}{l}\text { Togninia minima, Fomitiporia } \\
\text { mediterranea, } \\
\text { P. chlamydospora }\end{array}$ & $\begin{array}{l}\text { Coculture of the secreted } \\
\text { secondary metabolites and the } \\
\text { calli }\end{array}$ & Fungal growth rate & Bruno and Sparapano 2006 \\
\hline \multicolumn{4}{|l|}{ Leaf methods } \\
\hline $\begin{array}{l}\text { P. chlamydospore, } \\
\text { P. minimum, N. parvum, } \\
\text { D. seriata, Lasiodiplodia sp., } \\
\text { N. australe }\end{array}$ & $\begin{array}{l}\text { Detached leaves of grapevine } \\
\text { Italia, leaf disc assay }\end{array}$ & Necrosis development & $\begin{array}{r}\text { Abou-Mansour et al. 2015, } \\
\text { Andolfi et al. 2011, } 2016\end{array}$ \\
\hline \multicolumn{4}{|l|}{ Plantlet (Chardonnay cultivar) } \\
\hline $\begin{array}{l}\text { Botryosphaeria virulence } \\
\text { factors, toxins (mellein, } \\
\text { terremutin) }\end{array}$ & Incubation at root level & $\begin{array}{l}\text { Toxin removal (medium) and } \\
\text { plant uptake, physiological } \\
\text { parameters and plant gene } \\
\text { expression }\end{array}$ & Trotel-Aziz et al. 2019 \\
\hline \multicolumn{4}{|l|}{ Cutting } \\
\hline $\begin{array}{l}\text { Eutypa dieback, Eutypa lata; } \\
\text { the model can be adapted to } \\
\text { all other ascomycete wood } \\
\text { pathogenic fungi }\end{array}$ & $\begin{array}{l}\text { Insertion of a mycelial disc or } \\
\text { injection of a spore suspension } \\
\text { into a hole ( } 3 \text { to } 5 \mathrm{~mm} \text { ) }\end{array}$ & Development of necrosis & $\begin{array}{l}\text { Péros and Berger 1994, Chapuis } \\
1995\end{array}$ \\
\hline $\begin{array}{l}\text { P. minimum and } \\
P \text {. chlamydospore }\end{array}$ & & Gene expression study & $\begin{array}{l}\text { Pierron et al. 2016, Trotel-Aziz } \\
\text { et al. } 2019\end{array}$ \\
\hline Botryosphaeria dieback & & Molecular diagnostic & Pouzoulet et al. 2013 \\
\hline \multirow[t]{2}{*}{ N. parvum } & & $\begin{array}{l}\text { Microscopy analysis of woody } \\
\text { tissues }\end{array}$ & $\begin{array}{l}\text { Pouzoulet et al. 2013, Pierron } \\
\text { et al. } 2015 \mathrm{a}\end{array}$ \\
\hline & & Development of control tools & Pierron et al. 2015b, 2016 \\
\hline \multicolumn{4}{|l|}{ Grafted plant } \\
\hline $\begin{array}{l}\text { Botryosphaeria dieback, } \\
\text { N. parvum, D. seriata }\end{array}$ & Inoculation in the green stem & $\begin{array}{l}\text { Foliar symptoms expression, } \\
\text { size of necrosis, gene } \\
\text { expression }\end{array}$ & Reis et al. 2016 \\
\hline \multicolumn{4}{|l|}{ Pruning wound in field } \\
\hline $\begin{array}{l}\text { Eutypa dieback, Eutypa lata } \\
\text { and other Dyatripacae; the } \\
\text { model can be adapted to all } \\
\text { other ascomycete wood } \\
\text { pathogenic fungi }\end{array}$ & $\begin{array}{l}\text { Artificial contamination of the } \\
\text { pruning wound surface }\end{array}$ & $\begin{array}{l}\text { Development of infection in the } \\
\text { underlying wood tissues }\end{array}$ & $\begin{array}{l}\text { Carter 1991, EPPO 2017, } \\
\text { Lecomte and Bailey 2011, } \\
\text { Lecomte et al. 2003, } \\
\text { Sosnowski et al. } 2008\end{array}$ \\
\hline \multicolumn{4}{|l|}{ Stem in field } \\
\hline $\begin{array}{l}\text { Botryosphaeria dieback, } \\
\text { N. parvum, D. seriata }\end{array}$ & $\begin{array}{l}\text { Inoculation in the green stem } \\
\text { (third internode) }\end{array}$ & $\begin{array}{c}\text { Size of necrosis, gene } \\
\text { expression, proteins }\end{array}$ & Spagnolo et al. 2017 \\
\hline
\end{tabular}


monitor purification procedures. We also assume that the best fungal culture media to use are those that favor toxin production. Grapevine leaf assays can supply, at a microscale, information on the chemical profiles of extracts and fractions. They are useful in the early stages of purification and, therefore, significantly reduce the time for phytotoxin identification. These procedures are described according to Abou-Mansour et al. (2015) and E. Abou-Mansour (personal communication).

Leaves of plantlets are more sensitive than older ones taken from plants in the vineyard. Therefore, for the assay, intact, fully expanded young leaves taken from the vineyard or greenhouse should be used. Immediately after they are cut from the vines, they should be immersed in distilled water. When screening culture filtrates, care should be taken to adjust the culture medium to neutral $\mathrm{pH}$ before proceeding with the leaf assay. Extracts, fractions, or pure compounds may be diluted in 2 to $4 \%$ ethanolic or 2 to $4 \%$ aqueous dimethyl sulfoxide. It is necessary to include negative and positive controls in the assays in order to properly estimate the response regardless of the quantity of compounds analyzed. Concentration load by unit of leaf surface should be in a linear range of increased toxicity and should correspond to natural concentrations detected in the field. Three kinds of leaf assays can be considered and are discussed below: full-leaf, leaf-disc, or a leaf-drop method.

Leaf-disc method. Leaf discs were cut out in deionized water with a cork borer, avoiding major veins (Fig. 2). Water $(2 \mathrm{ml})$ containing a serial dilution of culture filtrate or known concentration of dissolved phytotoxins ( 100 to $500 \mathrm{\mu g} \mathrm{ml}^{-1}$ ), as described before, was placed into each well of a 12-well plate. Three to four discs $(5 \mathrm{~mm})$ or one disc $(9 \mathrm{~mm})$ were deposited in each well. The extent of necrosis was assessed after 24 and $48 \mathrm{~h}$ of incubation at room temperature. Eutypine at $200 \mu \mathrm{g} \mathrm{ml}^{-1}$ was used as a positive control.

Full-leaf method. In this assay, phytotoxicity screening was conducted on leaves by absorption of the toxins through the petioles. Leaves were cut from the vine and the petiole was immediately immersed in distilled water for $12 \mathrm{~h}$. Leaves were transferred to the phytotoxin solution for a defined time, then transferred to distilled water until necrosis appeared. Kinetics of the manifestation of the foliar symptoms, and of the volume of solution uptake, can be monitored. Symptoms such as browning or reddening followed by necrosis were observed with the toxins. Wagschal et al. (2007) reported that, with the higher concentrations of toxins identified from E. lata, there was a significantly greater uptake of solution by the detached leaf, suggesting increased transpiration.

Leaf-drop method. This method can be applied on a full leaf or a leaf disc with or without injury. Light injury was performed by gently pressing the tip of a pipette onto the leaf surface while applying the drop. In the case of full leaves, the petiole was cut close to the leaf base in a way that would allow maximum vascular contact with the water. The leaf, adaxial side up, was placed in sterile plates containing filter paper soaked in distilled $\mathrm{H}_{2} \mathrm{O}(2 \mathrm{ml})$, ensuring contact of the cut petiole with water (Fig. 2). The Petri dishes were kept in a laminar flow hood until the upper surface of the leaf had dried. The methods consist of depositing drops of 10 to $50 \mu \mathrm{l}$ of culture filtrate, culture extract, or phytotoxin solution on one side of the leaf surface. Drops of a negative control were placed to the other side. The dishes were sealed with parafilm and stored under bright fluorescent light with $16 \mathrm{~h}$ of light per day at $20^{\circ} \mathrm{C}$ until necrosis appeared. An additional volume of $\mathrm{H}_{2} \mathrm{O}(1.5 \mathrm{ml})$ was added to the Petri dish after $24 \mathrm{~h}$. A similar protocol can be applied to leaf discs where drops of phytotoxic solutions are deposited at the center of the leaf disc. Recording the intensity of lesions induced by different concentrations per droplet per leaf disc can be used to determine the minimal concentration that induces necrosis.

For all three leaf methods, the qualitative assessment of toxicity is based on visual observations of the extent of the necrotic lesions by a grading key from 0 to 4 , where 0 indicates no observable necrosis and 4 indicates complete necrosis. An alternative method is the measurement of chlorophyll levels, which provides a relative measure of tissue damage in the leaf disc (Smith et al. 2003). Today, open-source image processing programs designed for scientific multidimensional images such as Image $\mathbf{J}$ developed at the National Institutes of Health or APS Assess 2.0 software for plant disease quantification are available. These can be used for simple and rapid measurements of leaf area, lesion count, or necrosis percentage (Abou-Mansour et al. 2015; Andolfi et al. 2016).
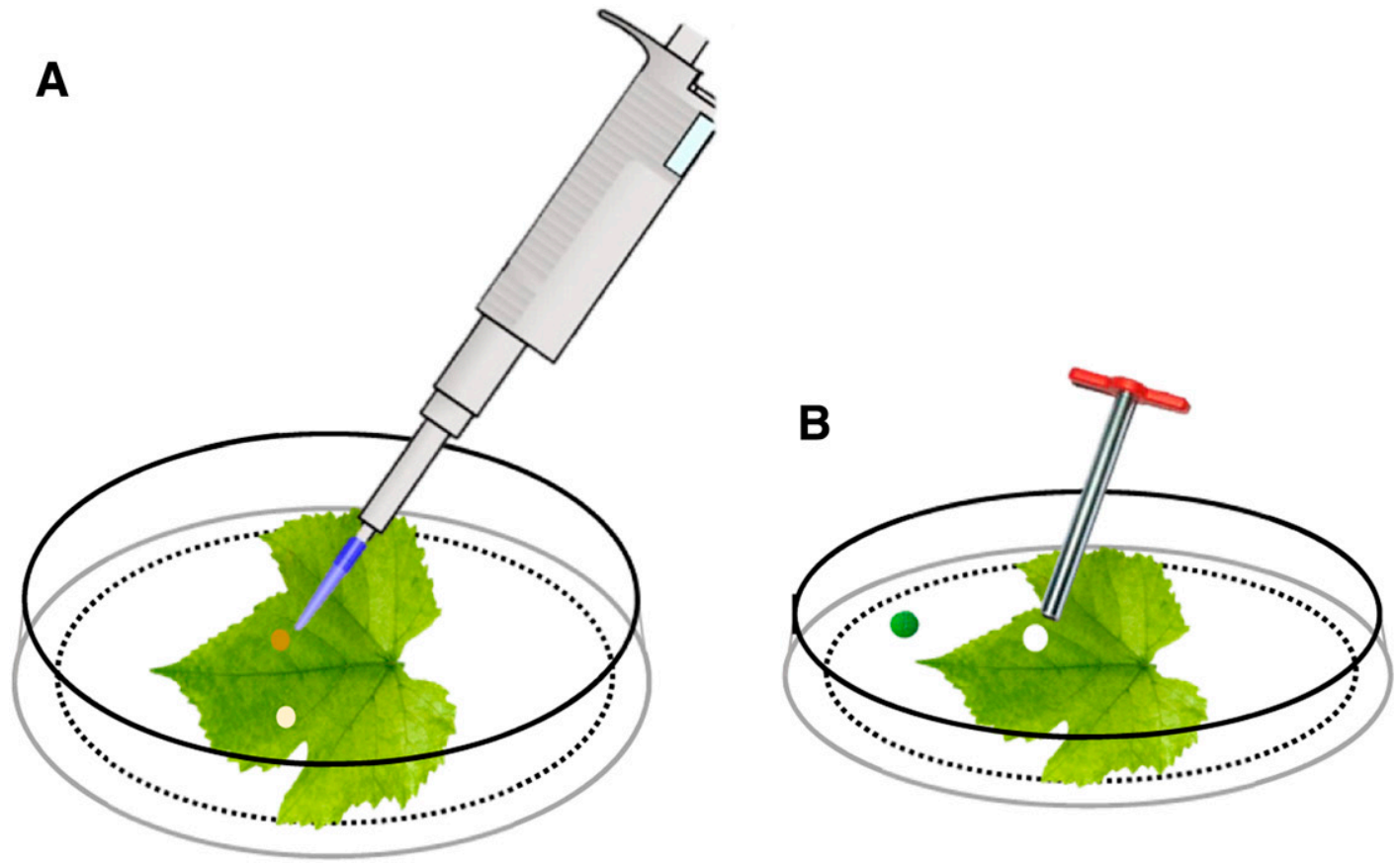

C

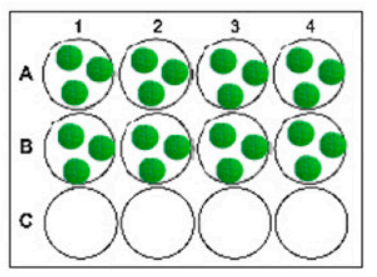

FIGURE 2

Leaf-drop and foliar disc methods for Vitis vinifera. A, On a Petri dish, a drop with fungal toxins is deposited on the adaxial side of leaf to test their toxicity. B, With a cork borer, leaf discs are excised and $\mathbf{C}$, transferred to a plate containing liquid medium with fungal compounds to test their toxicity. 
To investigate whether the phytotoxic activity of an isolated extract or compound is specific to vines, additional test plants such as tomato cuttings or Arabidopsis leaves should be used. If lesion development is observed on all three plants, it indicates that metabolites are nonhost-specific toxins. Several phytotoxins have been reported from GTD pathogens, apparently with different modes of action. Methods based on cell cultures are very rapid methods for screening large numbers of samples under highly controlled conditions and can also be very useful to help understand the specific interactions between GTD pathogens and grapevines on a molecular level. However, the way they interact with cellular methods based on cell cultures, alter membrane integrity, modify gene expression, or interact with plant enzymes to counteract metabolite biosynthesis are all aspects that remain to be elucidated.

In vitro whole-plantlet method to investigate detoxification and host defenses. In vitro whole-plantlet methods provide accurate data to fine tune our understanding of the toxin or the physiological and molecular effects of fungal toxins on grapevines. Indeed, the whole plant is considered in its simplest vegetative organization, making it easier to target and study the direct effects of toxins on the plant in in vitro entirely controlled conditions (Fig. 3). This method is often used to study the changes in grapevine basal or induced immunity in relationship with different diseases or elicitors (Gruau et al. 2015).

The procedures are as follows, according to Trotel-Aziz et al. (2019). Plantlets of Chardonnay clone 7535 were produced from nodal explants and transferred to $15 \mathrm{ml}$ of modified MS medium in 25-mm-diameter test tubes. Plantlets were grown at $25^{\circ} \mathrm{C}$ day and night, with a photoperiod of 16 and $8 \mathrm{~h}$, respectively, under white fluorescent lamps $\left(60 \mu \mathrm{mol} \mathrm{m} \mathrm{m}^{-2} \mathrm{~s}^{-1}\right)$ and, after 8 weeks, they were ready to be used for the experiments (Fig. 3). This method is useful for toxicity assessment, which is measured in terms of maximum quantum yield of photosynthesis ( Fv/Fm), which can be a sensitive indicator of the physiological condition of the plant, growth rate, and pigment concentrations after $72 \mathrm{~h}$ of exposure to GTD toxins such as $(R)$-mellein or (-)-terremutin added to liquid MS medium (Fig. 3) in a culture chamber at $20^{\circ} \mathrm{C}$ with a photoperiod of $16 \mathrm{~h}$ of light and $8 \mathrm{~h}$ of darkness. All experiments should be repeated four times, with each sample at least in triplicate. None of these markers changed below $1,500 \mu \mathrm{g}$ liter $^{-1}$, enabling investigation of the detoxification process within a nontoxic range of $(0$ to $1,500 \mu \mathrm{g}$ liter $^{-1}$ ).

For detoxification studies, 8-week-old plantlets were transferred to test tubes containing liquid MS medium supplemented or not with GTD toxins and incubated for 3 days under identical conditions in a growth chamber. Because no significant toxicity was noticed below $1,500 \mu \mathrm{g} \mathrm{liter}^{-1}$ with $(R)$-mellein or (-)-terremutin, all experiments using these phytotoxins were performed with $(R)$-mellein at $350 \mu \mathrm{g}$

FIGURE 3

Plantlet model for Vitis vinifera treatment with the toxins associated with grapevine trunk disease fungi. Left side shows the plantlet model (photo and diagram) as described by our team. Right side shows the plantlet transferred to a new tube containing fresh liquid incubating medium supplemented with toxin. liter ${ }^{-1}$ or with (-)-terremutin at $750 \mu$ gliter $^{-1}$ (Trotel-Aziz et al. 2019). To perform detoxification studies, the applied phytotoxin concentration should be as weak as possible but above the highperformance liquid chromatography (HPLC) detection threshold if the aim is to quantify it over time. To investigate grapevine responses or defenses, plantlets for RNA extraction and reversetranscription polymerase chain reaction (PCR) analysis were collected 3 days postinoculation and stored at $-80^{\circ} \mathrm{C}$ until extraction, as described by Gruau et al. (2015). To investigate grapevine detoxification capacity, phytotoxins were extracted and quantified as described by Trotel-Aziz et al. (2019). Two different controls were required: the living plants in a toxin-free medium and the medium containing only toxin without living plants. Toxin removal from the plant-incubating medium was also investigated by directly injecting an aliquot of the (-)-terremutin-containing medium into the HPLC system, while $(R)$-mellein was extracted with hexane (10:2 [vol/vol]) before analysis.

Thus, this last in vitro plantlet model can refine the toxicity tests (micrograms per liter compared with micrograms per milliliter applied to calli) but it is most interesting for detoxification studies, investigating both the host physiological and molecular changes as well as the transport, bioaccumulation, and metabolization of molecules delivered by a GTD pathogen. This in vitro method also offers the potential to first screen the efficient plant response associated or not with beneficial microorganisms (Trotel-Aziz et al. 2019). Nevertheless, all of these interesting and valuable informative in vitro models do not allow direct experimentation with the GTD pathogens; only the in vivo models allow such an approach.

\section{IN VIVO ARTIFICIALLY INOCULATED PLANT ASSAYS, TO REPRODUCE WOOD AND FOLIAR SYMPTOMS AND TO VALIDATE PATHOGEN CONTRIBUTION TO NATURAL GTD SYMPTOMATOLOGY}

This laboratory method was first developed to directly investigate pathogen contribution to GTD symptomatology and ways of possible control. Such bioassays are also suitable to investigate trunk microbial ecology, useful for nursery diagnosis and in field conditions. In most cases, 1-year-old cuttings were used to focus on early events in grapevine-GTD pathogen interactions. This model aims to (i) to study multidirectional interactions at tissue, cellular, and molecular levels between pathogens themselves, pathogens and vine, and pathogens and vine-microbiome and (ii) provide an easyto-handle biological tool to test any control compound or agent to limit the progression of GTD-associated fungi. The model is adapted depending on the GTD pathogen; therefore, they are described individually (Table 2).

\section{Plantlet model}
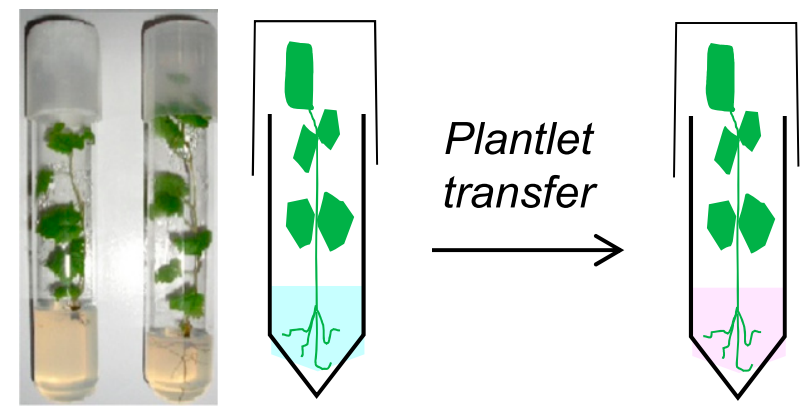

\section{Incubating medium (agar or liquid)}

Liquid medium with toxin 
A method for Eutypa dieback, the first one available. At least two simple approaches are currently used to reproduce E. lata infections and typical foliar symptoms in cuttings. The earliest methods for this pathogen were probably those described by Mur (1979) in Europe with two methods: (i) using rooted plants of Sauvignon Blanc grafted onto Rupestris du Lot rootstocks and inoculated by placing mycelium of a strain isolated from grapevine into the graft union, and (ii) using unrooted cane segments inoculated with Eutypa mycelium close to the upper bud after taking out the pith. Petzoldt et al. (1981) inoculated pruning wounds of 1-year-old rooted grapevines with E. armeniacae ascospores and observed typical symptoms the following growing season. The first researcher to use the rooted cuttings method was Chapuis (1995). Canes were collected during the dormant season; two-internode cuttings were rooted for 2 months before inoculation and grown in a greenhouse. The temperature was controlled between 20 and $24^{\circ} \mathrm{C}$. Plants were watered for $5 \mathrm{~min}$, twice each day with 1.89 liters/h via a drip system. They received $18 \mathrm{~h}$ of light per day from both ambient and supplemental lighting. Plants were inoculated following the method described by Chapuis (1995): a wound (4 to $5 \mathrm{~mm}$ in diameter, $\pm 5 \mathrm{~mm}$ deep up to the pith) was drilled 1 to $2 \mathrm{~cm}$ below the upper bud. Inoculum can be mycelial plugs taken from the margin of 7-day-old cultures and inserted into the wound, a mycelial pellet collected by scraping the surface of the fungus growing on agar medium (Jung et al. 2010), or mycelial or spore suspensions in water introduced by injection with a pipet into the hole in the cutting (different volumes can be used) (Fig. 4). A cultivar known to be susceptible to Eutypa dieback (Cabernet Sauvignon or Sauvignon blanc) is generally preferred, especially to compare the virulence of GTD fungal strains. The use of aggressive strains is recommended when the purpose is to test cultivar susceptibility to GTD (Péros and Berger 1999). To ensure that an artificial niche is not created, inoculation sites are not covered or wrapped with any protective plastic film but are sealed with warm wax only. Noninoculated control vines treated with an agar plug or sterile water are generally included in the experimental designs. Cuttings are maintained in a greenhouse or under a shadehouse until typical Eutypa foliar symptoms appear the following year in spring after bud break. To date, this method has been routinely used to examine the susceptibility of cultivars visually and at the molecular level (Camps et al. 2010, 2014) and to test the efficiency of control products (P. Lecomte, personal communication). M. J. Creaser, a researcher from the South Australian Research and Development Institute in Adelaide, imported this method into Australia after her visit in 2001 to Bordeaux (France) to test cultivar susceptibility (Sosnowski et al. 2007) and also to test the effect of water and temperature stress on disease severity. Since then, many authors have used similar or derived methods with GTD pathogens and for diverse epidemiological studies (Laveau et al. 2009).

The method based on using unrooted cuttings is similar to the method based on rooted cuttings, except that there is rapid expression of foliar symptoms, which appear in less than 2 months (Péros and Berger 1994). The one-internode cuttings are placed and maintained in moist rock-wool rolls or in sand terrines for approximately 3 months. Inoculations are made in the same way as described above. Symptoms appear 4 to 8 weeks after inoculation
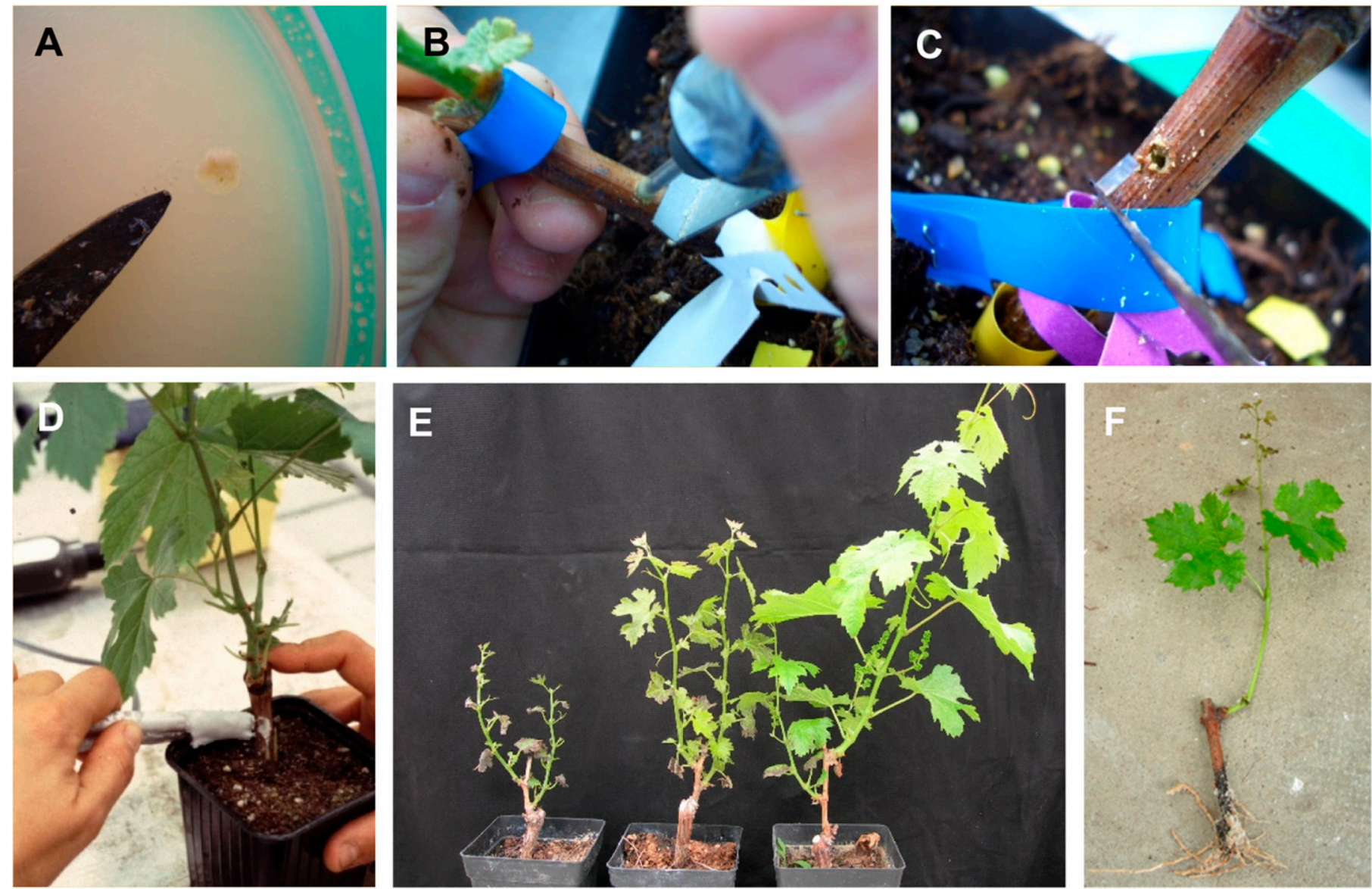

\section{FIGURE 4}

Process developed to reproduce Eutypa lata symptoms with unrooted or rooted cuttings of Vitis vinifera, as described by Péros and Berger (1994) and Chapuis (1995). A, Inoculation preparation. A pellet of $E$. lata sampled on a 1-week-old mycelium culture in petri dish. B, Perforation of the woody stem. On the 1-year-old lignified stem, a hole (4 to $5 \mathrm{~mm}$ in diameter) under the upper bud produced with a drill. C and $\mathbf{D}$, Artificial inoculation of rooted cutting. The pellet, spores or a plug of $E$. lata is put in the stem hole. $\mathbf{E}$ and $\mathbf{F}$, Foliar symptoms of $E$. lata on 1-year-old rooted cuttings. 
and their development is generally recorded twice at intervals of 2 and 4 weeks. Mur (1988) was probably the first researcher to obtain a high incidence of foliar symptoms using this method. Péros and Berger (1994) were the first to use it to compare the aggressiveness of isolates and the susceptibility of cultivars before they used it to study the diversity of natural E. lata progenies (Péros and Berger 1999). This rapid method was also used in Australia by Sosnowski et al. (2007).

A method available for esca complex diseases with Phaeoacremonium minimum and Phaeomoniella chlamydospora. Two methods to infect plants with $P$. minimum have been developed and these are based on nodal or internodal inoculation described by Pouzoulet et al. (2013) (Fig. 5). Wounds were treated with fungal mycelium or spores and the infection allowed to develop for $10 \mathrm{~h}$ to 12 weeks postinoculation. This model was completed with the design of a quantitative PCR (qPCR) plexor analysis to detect and follow fungal development (Pouzoulet et al. 2013); green fluorescent protein ( $g f p$ ) transformants of $P$. minimum (Pierron et al. 2015a) and $P$. chlamydospora were used for confocal microscopy observations to study gene expression in grapevine woody material (Pierron et al. 2016).

In the above studies, 1-year-old canes of Cabernet Sauvignon clone 15 were used and the general procedure was as follows. Canes were surface sterilized in a fungicide bath containing $0.05 \%$ Cryptonol (8-hydroxyquinoline sulfate at $140 \mathrm{~g} /$ liter; Syngenta) for $1 \mathrm{~h}$ and stored at $4{ }^{\circ} \mathrm{C}$ until further processing. Canes were divided

FIGURE 5

Cutting inoculation procedure for Vitis vinifera wood with esca-associated fungi. The left side describes the internodal model and the right side the nodal model inoculation methods. I, Plants carrying one or two branches are maintained in a growth chamber for 1 week. The internodal infection consists of wounding damage at the middle of an internode. I bis, For the nodal model, the intermediate branch is cut with a blade. II, Wounding damage is done using a drill bit. III, Escaassociated fungi are deposited in the wound. into cuttings with three dormant buds (nodal treatment) or cuttings with two dormant buds (internodal treatment). Cuttings were soaked in a water bath containing bleach and were stored at $4^{\circ} \mathrm{C}$ overnight in a solution of $0.05 \%$ Cryptonol, then given successive washes before planting in plastic trays filled with moistened autoclaved glass-wool. The cuttings were kept in a growth chamber (photoperiod of 16 and $8 \mathrm{~h}, 25^{\circ} \mathrm{C}, 90 \%$ humidity) and watered as necessary. Budding and rooting takes 4 to 6 weeks before the cuttings are potted in $75 \mathrm{cl}$ pots containing a sterile mixture of perlite, sand, and turf $(1: 1: 1 \quad[\mathrm{vol} / \mathrm{vol}])$. Cuttings were then transferred to a growth chamber (photoperiod of 16 and $8 \mathrm{~h}$, $25^{\circ} \mathrm{C}, 45 \%$ humidity) and plants remained there for at least 1 week before treatments to avoid potting stress (Fig. 5I). Cuttings were inoculated when at least six leaves were fully developed (Fig. 5II). First, cuttings were partially surface sterilized by wiping with a tissue sprayed with $70 \%$ ethanol. For internodal inoculation, a wound was made at the internode by drilling with an ethanol-flamed 3-mm drill bit and inoculum was introduced into the wound. After inoculation, the wound was covered with cellophane. Inoculum was either spores or hyphae taken from cultures growing on agar plates (Fig. 5III). For nodal inoculation, the branch formed from the middle node was cut with an ethanol-flamed blade (Fig. 5I). A wound was then made at this nodal level with an ethanol-flamed 3-mm drill bit and inoculated as described for the internodal inoculation. Following inoculation at both internodal and nodal levels, plants were maintained in the growing chamber under the

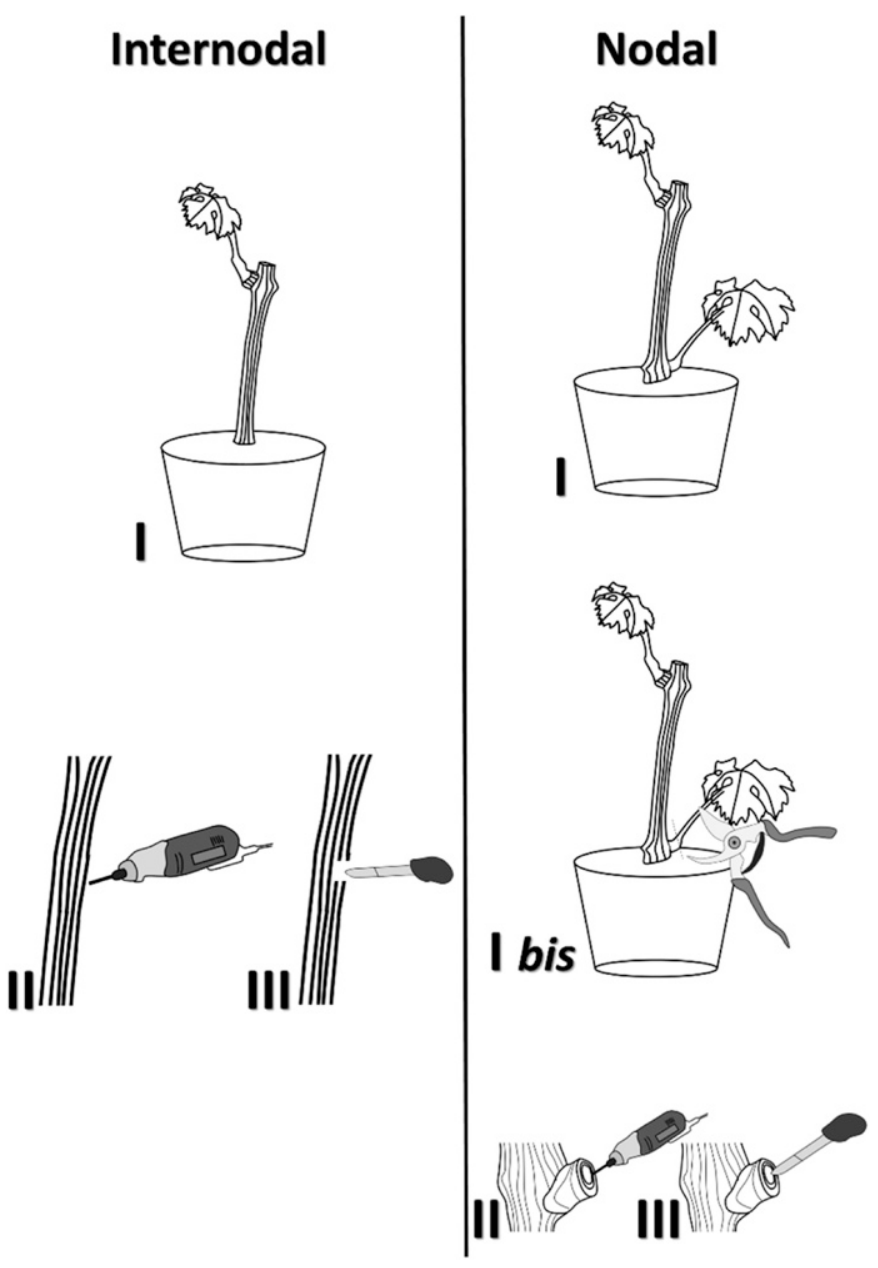


same conditions and watered every second day with autoclaved tap water. When screening for biological or chemical agents to control the development of esca-associated fungi, the wound can be treated prior to or following inoculation with the pathogen.

Thanks to this model, understanding of the early stages of colonization by esca-associated fungi in woody tissue has increased. First of all, the type of woody tissue greatly influenced fungal colonization. P. minimum colonized a wound at the internode 6 weeks postinoculation, whereas it was restricted at the nodal inoculation site. Interestingly, nodal tissues presented an intense fluorescent barrier that may be involved in slowing down $P$. minimum infection. However, the fungus was able to overcome plant responses 12 weeks postinoculation. These results orientated our investigation on the internodal response to pathogen colonization and suggested that grapevine wood may respond to $P$. minimum (Pierron et al. 2015a). We could describe the healing modification caused by $P$. chlamydospora by using the internodal model (Pouzoulet et al. 2013). A strong reduction of healing tissues in plants infected with $P$. chlamydospora compared with damaged noninoculated plants was observed. This result, associated with the fact that we could describe the fungal colonization via microscopic analysis of calcofluor-stained samples, revealed the capabilities of $P$. chlamydospora to modify plant tissue response within weeks after inoculation. Healing was also analyzed in P. minimum-inoculated plants but the response was opposite to $P$. chlamydospora, because $P$. minimum did not modify tissue responses compared with untreated wounds (Pierron et al. 2016). In the case of coinoculation of $P$. minimum and $P$. chlamydospora, we observed an intermediate phenotype of healing tissues at the wounding site. To detail early niches of colonization of $P$. minimum via internodal sites of inoculation, we developed a $g f p$-tagged strain of $P$. minimum. Xylem vessels were colonized by the fungus within 12 weeks postinoculation via xylem fibers (Pierron et al. 2015a). The colonization niches observed for the $P$. chlamydospora $g f p$-tagged strain were consistent with the previous study by Fleurat-Lessard et al. (2010). This $g f p$-transformed strain was later used in a transcriptomic study in the presence of $V$. vinifera callus (Fischer et al. 2016). The particular barrier formation observed after nodal inoculation, together with the different healing response at the internode according to pathogen species, suggested a certain level of perception by the woody tissues. Induced defense and pathogen perception in the trunk were investigated by a molecular method. This model allowed gene expression to be studied in wood in response to $P$. minimum or $P$. chlamydospora inoculation in the internodal region. Despite the strong background noise induced by plant response to the wounding stress, our data revealed that (i) woody tissue perceived and reacted to $P$. minimum or $P$. chlamydospora, (ii) molecular responses differed slightly between $P$. minimum and $P$. chlamydospora treatments, and (iii) molecular responses differed between coinoculation with the two pathogens compared with inoculation with a single pathogen (Pierron et al. 2016).

The method was also developed as an easy tool to test the ability of compounds to restrict fungal growth inside the wood. In that sense, the nodal model was used to analyze the potential effect of elicitors (Pierron et al. 2016). We showed the capabilities of ozone dissolved into water to limit $P$. minimum growth with the nodal model (Pierron et al. 2015b). Fungal growth was monitored by qPCR. This tool can also detect the number of DNA copies present in wood samples and, thus, can be used as a diagnostic tool. Overall development of this model gave the communities investigating GTD a tool to study wood responses at different levels to escaassociated fungi.
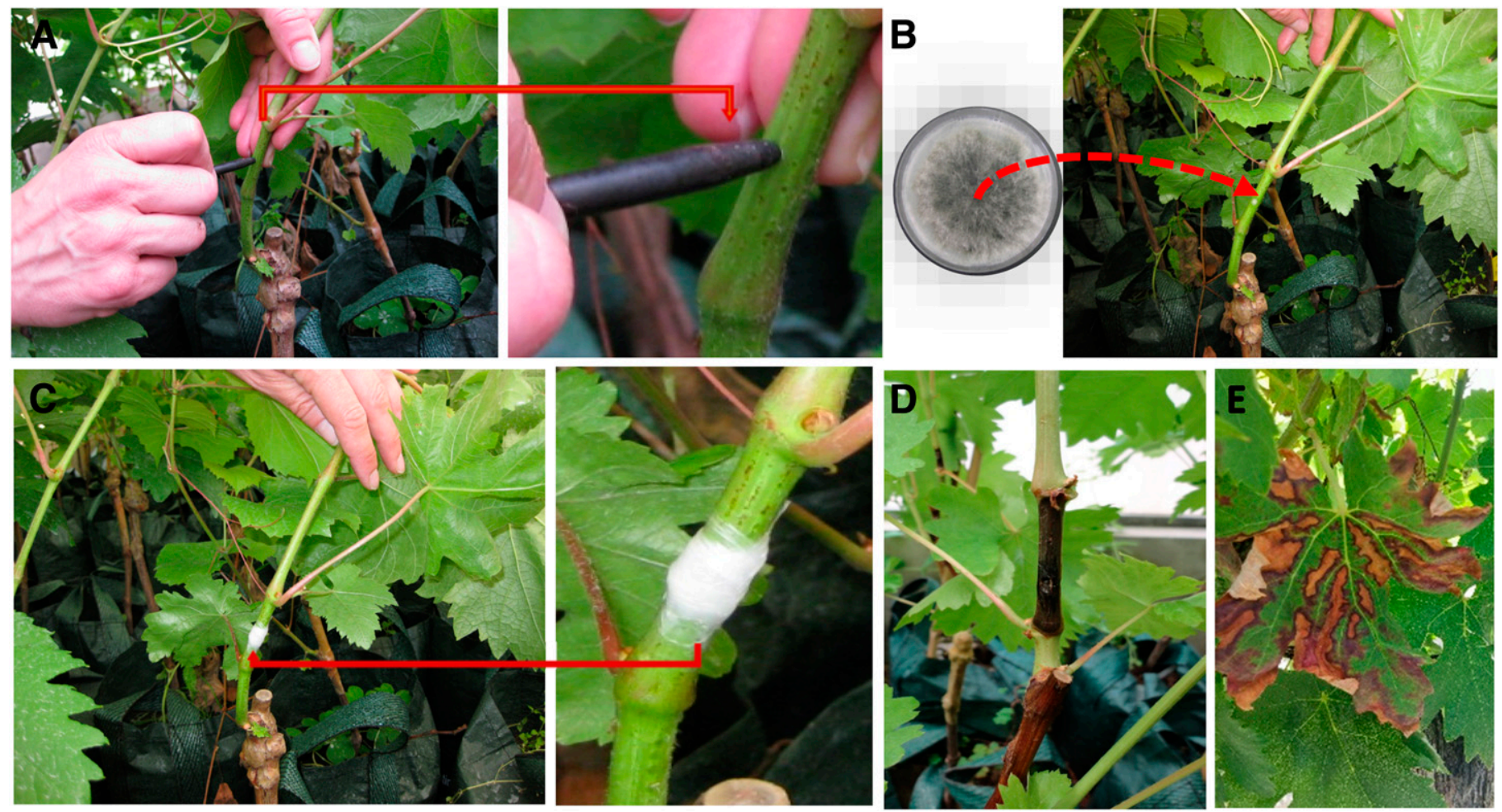

FIGURE 6

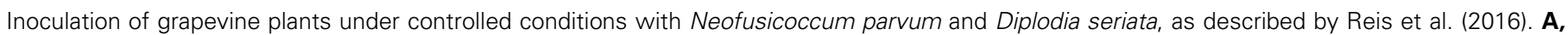

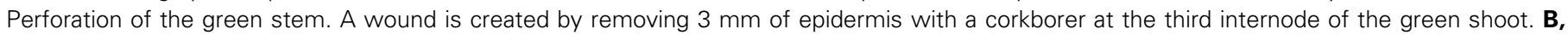

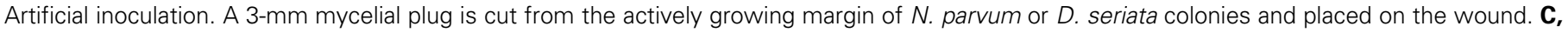

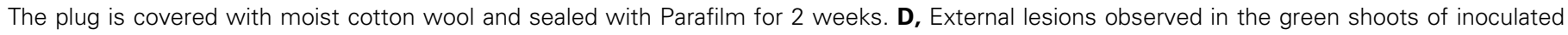
plants. E, Foliar symptoms expressed on inoculated plants. 
To conclude, with this laboratory method, the microbial ecology within the trunk of young grapevines can be studied. In this way, it focuses on early events involved in the esca pathosystem. It has been used to confirm that trunk-induced responses exist and may be specific to the fungal species colonizing the plant. The response was also associated with a difference in wound healing according to the fungal species. The model also allows for a rapid screening of candidate compounds for control of esca-associated fungi.

A method for some species associated with Botryosphaeria dieback. According to Urbez-Torres (2011), Botryosphaeriaceae species that infect grapevines can be divided into three different groups based on their aggressiveness (high, moderate, and low), where Lasiodiplodia spp. and Neofusicoccum spp. belong to the highly aggressive group, Botryosphaeria dothidea and Diplodia spp. to the moderately aggressive group, and Dothiorella spp. and Spencermatinsina viticola to the slightly aggressive (low) group. For Botryosphaeria dieback, pathogenicity trials have been conducted, showing lesions at the initial inoculation point (Taylor et al. 2005; Úrbez-Torres and Gubler 2009). On leaves, such inoculation could induce sudden dry shoots (Larignon et al. 2015; Mohammadi et al. 2013; Úrbez-Torres and Gubler 2009) or discoloration (Reis et al. 2016). Reis et al. (2016) presented an assay where inoculation of 1-year-old grafted Tempranillo with Neofusicoccum parvum and $D$. seriata induced lesions on the stem and discoloration on leaves. For that model, 1-year-old grafted cuttings were potted individually in 1-liter, free-draining bags containing a sandy soil mixture and arranged as a complete randomized design in a ventilated greenhouse at $24^{\circ} \mathrm{C}$ under natural light. After 1 month of growth, plants were inoculated with $N$. parvum and D. seriata by removing a $3-\mathrm{mm}-$ diameter area of the bark with a cork borer from the base of the primary stems (approximately $1.5 \mathrm{~cm}$ in diameter) between the second and third nodes (Fig. 6). Wounds were inoculated with 3-mmdiameter mycelial plugs taken from the actively growing margin of 8 -day-old colonies grown on potato dextrose agar (PDA) at $24^{\circ} \mathrm{C}$ in darkness. Each inoculation point was covered with moist cotton wool and sealed with parafilm (Fig. 6). Positive and negative controls were inoculated using the same method, but with 3-mm-diameter mycelial plugs of other grapevine pathogens and sterile 3-mm-diameter PDA plugs to confirm that lesions were due to infection by Botryosphaeria dieback pathogens. The experiment was done in a greenhouse and emergence of foliar symptoms was observed 8 months after inoculation. The dimension of external lesions was evaluated 3 months after inoculation on green shoots, before lignification occurs, by measuring the width and the length of the lesion. The percentage of grapevines that showed symptoms was recorded when one or more leaves had chlorotic areas (the plant was considered positive for symptom expression). To fulfill Koch's postulates, small pieces of necrotic tissue were taken from the edge of each lesion and incubated on PDA amended with chloramphenicol at $250 \mathrm{mg} \mathrm{liter}^{-1}$ to recover the inoculated fungi.

Thanks to this model, it was possible to show that $N$. parvum isolates produced longer lesions with greater surface area than
D. seriata isolates in Tempranillo (Reis et al. 2016). In regard to foliar symptoms, it has been demonstrated that $N$. parvum and $D$. seriata can produce cell-wall-degrading enzymes and phytotoxic metabolites. Their synergistic action could play an important role in the development of foliar symptoms (Andolfi et al. 2011; Bellée et al. 2017). Both production and identification of phytotoxic metabolites have been reported (Abou-Mansour et al. 2015; Andolfi et al. 2011; Martos et al. 2008) but their exact roles remain unclear. Their accumulation in plant tissues suggests a potential effect during the appearance of foliar symptoms (Bellée et al. 2017). Nevertheless, further work needs to be carried out to elucidate the entire mechanism that modulates cultivar susceptibility toward phytotoxic fungi and to better understand the ability for $N$. parvum and $D$. seriata to synthesize and secrete more or less potent phytotoxic compounds (Abou-Mansour et al. 2015). These studies will allow a better understanding of the molecular dialogue between fungi and plants (Reis et al. 2016; Trotel-Aziz et al. 2019).

The main advantage of this assay is that the pathogens are rarely isolated other than in the wood, and artificially infected plants respond similarly to plants naturally infected in the vineyard. Thus, it can provide useful data to better explore the aggressiveness of species of Botryosphaeriaceae toward cultivars at morphological, physiological, and molecular levels and in relationship to the quantitative and qualitative production of fungal metabolites.

\section{FIELD VALIDATION BY ARTIFICIAL INOCULATION OF PRUNING WOUNDS AND STEMS, THE LAST EXPERIMENTAL STEP}

Among the methods available in vineyards, artificial inoculation of both pruning wounds and stem have been developed and used according to the goals of the study (Table 2).

Artificial inoculation of pruning wounds, the main route for GTD pathogen infection. The first publications that reported this method were with E. armeniacae on apricot in the 1970s (Carter and Moller 1971; Ramos et al. 1975). These studies were the origin of methods developed from the 1980s for inoculation of grapevines either using ascospores or mycelium (Carter 1991). Inoculum with ascospores is generally preferred and methods differ mostly in the inoculum dosages, length of incubation periods, or isolation procedures (Elena et al. 2015). One of the first rapid methods for screening compounds for disease control, or to study the susceptibility of cultivars, was carried out in France and was based on inoculation of pruning wounds (Paillassa 1992).

The concept is always the same: a cane is pruned, the wound is artificially inoculated, and the fungus is recovered by isolation after incubation (Fig. 7). Different procedures are used in the vineyard, under greenhouse conditions, or in a climatic chamber. Only two of these methods used with E. lata infections are presented here: the first one is used worldwide and is presently an official method for the regulation of disease control products in European countries

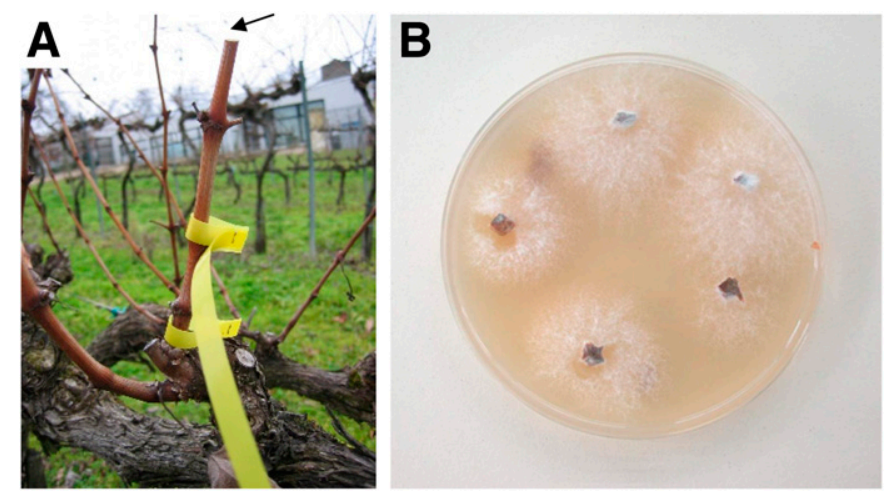

FIGURE 7

Pruning wound methods in the vineyard, as described by Lecomte et al. (2003). A, In the vineyard, inoculation with 50 to 250 spores of Eutypa lata at the pruning of the canes composed of 2 to 3 internodes. $\mathbf{B}$, In the laboratory, 5 pieces of wood from the pruning wound inoculation site were deposited onto culture medium and grown for 4 to 7 days. 
(EPPO 2017) and the second method enables rapid results and is included in an official French regulation method (Method CEB 155, third edition) aimed at the efficacy evaluation of disease control compounds. The same rationale was used by others for the rapid screening of pruning wound protectants (Ayres et al. 2011; Lecomte et al. 2003; Rolshausen et al. 2010) or for epidemiology (Chapuis et al. 1998; Lecomte and Bailey 2011). The field trial should be set up preferably in a young vineyard during winter dormancy. A preliminary disease assessment, done the year before the trial, can help ensure that the selected vineyard is free from Eutypa dieback. Although the infection of dormant wood from a tolerant grapevine cultivar may also be successful, a standard susceptible cultivar is generally used for these field trials. An experimental design with four blocks is recommended with at least eight marked canes per block. Canes were pruned, leaving from 1 to 3 internodes from the base and more or less $2 \mathrm{~cm}$ above the nearest bud. Because E. lata conidia do not germinate and cannot be used for experiments, artificial inoculations should be made with ascospores. These were collected from perithecia previously harvested from local vineyards. Different methods can be used to collect ascospores from stromata: (i) perithecia collected from stromata with a scalpel are immersed in sterile water for approximately $1 \mathrm{~h}$, (ii) a piece of moistened stromata is attached to a Petri dish lid with modeling clay and ascospores eject into water in the base of the dish (Carter 1991), or (iii) perithecia are cut open with a scalpel and a droplet of sterile water is applied to the cut surface (Trouillas et al. 2010). The concentration of ascospores in the suspension was adjusted to 5 to 10 spores/ $\mu$ l. Then, 20 to $25 \mu$ l of the selected suspension was deposited with a micropipette onto the center of each pruning wound, representing 100 to 250 spores/wound. It is possible to reduce the inoculum pressure for trials in the vineyard but a minimum of 50 spores inoculated per wound is recommended. After a minimum incubation period of 8 months in the field, isolations were made from each cane sample by culturing wood chips on a suitable culture medium. Canes were collected with one to two internodes, and new young shoots were removed before transfer to the lab. The upper parts of the canes were lightly cleaned and surface disinfested by wiping with a piece of cotton soaked with $90 \%$ ethanol, then quickly passed through a flame. The bark was removed with a sterilized scalpel which was regularly disinfected, and the canes were again briefly flamed. At the pruning wood surface, a necrosis of $2 \mathrm{~cm}$ developed and could reach the nearest bud zone. The first 1 to $2 \mathrm{~mm}$ of cane was cut using pruning shears to remove tissues where many saprophytic organisms are often present. Then, 25 small wood chips of approximately 20 to $30 \mathrm{~mm}^{3}$ ( 3 by 3 by 3 to $4 \mathrm{~mm}$ ) were cut from the necrotic wood, surface disinfested by immersion in a $3 \%$ solution of calcium hypochlorite for a few seconds, then placed on malt extract agar or PDA in Petri dishes ( 5 wood chips per dish). The observation of E. lata mycelium derived from a single wood chip was sufficient to confirm that the respective cane is infected. The results were expressed in the number of canes infected with E. lata relative to the number of canes analyzed and presented as infection percentages.

Before the tests for efficacy of disease control compounds on pruning wounds in the vineyard, a rapid trial in a climatic chamber was conducted initially to screen candidate compounds. For that, canes were collected during the winter, wrapped in a semiclosed plastic bag, and kept in cold storage until use. They were cut into 32 lengths of approximately $20 \mathrm{~cm}$ (two to three internodes) and placed as cuttings in pots filled with sterilized wet sand. The bark of the canes was surface disinfested with a swab soaked in alcohol before pruning. The pruning cut was made 2 to $3 \mathrm{~cm}$ above the nearest bud. Canes were treated according to the trial objectives and inoculated as described above for the trial in the vineyard. Pots were then placed in a climatic chamber at 10 to $15^{\circ} \mathrm{C}$. Mycelial development was enhanced by reproducing one or two morning dews by lightly spraying the wounds with sterile water. After an incubation period of from 15 days to 1 month, the ends of canes were cleaned and surface disinfested by swabbing with cotton wool soaked with alcohol and then quickly flamed. The bark was peeled off with a sterilized scalpel, which was regularly disinfected by dipping in alcohol and flaming. Debarked tops of canes were rapidly heated over a flame, then cut with a cutter into at least eight slices, each approximately $1 \mathrm{~mm}$ thick. The cutter should be kept sterile to avoid cross-contamination of the slices. The slices were then deposited, in the order they were cut, on an agar medium in Petri dishes (4 slices/dish) that was previously marked so that it was possible to identify the order of the slices at the time of scoring.

To conclude, although rapid methods are useful to obtain preliminary results, the classical method of inoculations in the vineyard after a sufficiently long period of incubation is generally considered more reliable to allow an easier recovery of the inoculated pathogen after mycelial development. This is a key aspect, especially for the evaluation of organic control agents, to avoid false-negative results with fungal antagonists such as Trichoderma spp. or other fast-growing microorganisms that may overgrow the colonies of the slow-growing pathogens. Artificial pruning wound infection has been widely applied worldwide in studies on the control or epidemiology of Eutypa dieback (Chapuis et al. 1998; Lecomte and Bailey 2011; Moller and Kasimatis 1980; Rolshausen et al. 2010; Sosnowski et al. 2008).

Artificial inoculations of green stems. In the vineyard, this model was first used to identify the periods of cultivar susceptibility to species of Botryosphaeriaceae (Spagnolo et al. 2017). The concept was to inoculate the pathogen into a shoot at different phenological stages (separated clusters, flowering, or veraison) to evaluate its behavior at each targeted stage by measuring the length of the necrosis and to determine plant physiological changes by proteomic or transcriptomic methods. With this method, it was also possible to identify the influence of the inoculum load on the host-pathogen interaction.

The trial must be conducted on a susceptible cultivar. At the phenological stage chosen, stems were wounded longitudinally with a sterile scalpel at the middle of the third internode. The wounds ( $8 \mathrm{~mm}$ long, $1 \mathrm{~mm}$ deep, and $5 \mathrm{~mm}$ wide) were inoculated, by inserting into the wound a 5-mm-diameter plug of agar taken from the edge of a 5-day-old actively growing fungal culture. Controls were inoculated with sterile plugs of the agar medium. The inoculation sites were then covered with Parafilm. Each condition was replicated eight times, with one repetition per plant. Both injured and inoculated shoots and controls were selected on different vines. Observations on lesion development and reisolations were performed after harvest for each treatment from all phenological stages, as described by Larignon and Dubos (1997). The shoot at the level of the third internode was cut longitudinally and the length of necrosis was measured on both sides from the point of inoculation. Ten sections cut from the necrosis were collected, disinfested with $3 \%$ calcium hypochlorite, and placed in Petri dishes of malt extract agar (15 g of malt and $20 \mathrm{~g}$ of agar per $1,000 \mathrm{ml}$ of water) and incubated at room temperature $\left(20\right.$ to $\left.25^{\circ} \mathrm{C}\right)$. Observation of mycelium typical of Botryosphaeriaceae spp. was needed to confirm the infection of the shoot. Samples for RNA or protein extraction were collected 20 days after inoculation from the portion of the inoculated internode (the corresponding wounded internode, for controls). Immediately after collection, samples were frozen in the field with liquid nitrogen and subsequently stored at $-80^{\circ} \mathrm{C}$.

Thanks to this model, the relationship between the pathogen and the plant has been investigated in various conditions of the vineyard (Spagnolo et al. 2017). It can be used to (i) compare the aggressiveness of different strains of the same species, (ii) compare the behavior of different grape varieties planted under the same pedoclimatic conditions and challenged by the same strain of the pathogen, or (iii) evaluate the influence of cultural practices or the 
effectiveness of plant protection products on disease development. Contrary to the methods using grapevine cuttings cultivated under greenhouse conditions, the weather conditions are not controlled under field conditions and, thus, the experiments must be carried out over several years.

\section{DISCUSSION OF THE STRENGTHS, WEAKNESSES, AND COMPLEMENTARITIES OF THE METHODS}

Due to the diversity of GTD fungi, together with the fact that grapevine is a perennial plant grown in widely different climate and cultural conditions around the world, there are great difficulties in developing a model to decipher GTDs. It is essential to understand the mechanisms deployed in woody tissues against pathogens, because the molecular dialog between plant cells and GTD pathogens remains poorly understood. There is, currently, strong overall knowledge of the symptomatology and characteristics of GTD fungi but, although foliar symptoms are visible, the pathogens are rarely found elsewhere than in the wood. It was hypothesized and subsequently demonstrated that GTD fungi are able to produce several metabolites such as cell-wall-degrading enzymes and phytotoxic metabolites that are translocated from the infected woody tissues in the trunk to the aerial part of the affected vines, and their synergistic action may play a role in the emergence of foliar symptoms (Mugnai et al. 1999). Meanwhile, studies on defense responses induced by GTD fungi have been conducted on plants in the vineyard showing differential expression of foliar symptoms (Bertsch et al. 2013). Nevertheless, host-pathogen field trials are complex because various pathogens are involved. This imposes additional problems such as (i) field results can be misleading and they frequently differ significantly from one year to another because of different environmental conditions and (ii) they do not separate the effect of the pathogen from the effects induced by other biotic or abiotic agents present in the environment.

The methods developed and described in this review aim to provide useful tools to acquire new and more profound knowledge of the interactions between grapevines and GTD pathogens. It is expected that this will lead to the development of new and improved management strategies.

In vitro methods. By using in vitro methods, several studies of the interaction between the plant and the molecules delivered by pathogens have shown that the use of callus tissue can be of interest, especially to rapidly test a large number of GTD fungal metabolites associated with aggressiveness. They can also be used to prescreen and preevaluate cultivars so that those that show promising resistance to GTDs can be included in new breeding programs. Moreover, callus tissues can be used to acquire greater knowledge about early plant defense reactions, which could be induced in the fast senescence symptoms in response to pathogen infection. Callus tissue can be an interesting first tool to study host-aggressive molecule interactions because they are grown in controlled conditions. For this reason, callus has been used previously for studies of several different plant species such as elm trees (Pijut et al. 1990) and potato (Behnke 1979). Grapevine calli have been used to understand the effect of toxins and to assess the virulence of esca-associated fungi (Santos et al. 2005; Sparapano et al. 2001). They have also been used to study the response of $P$. minimum and $P$. chlamydospora to the $V$. vinifera environment by analyzing the transcriptomes of both fungi in axenic or mixed cultures with plant cells (Fischer et al. 2016).

For Botryosphaeria dieback, these in vitro cellular assays have been used by Ramírez-Suero et al. (2014), in which extracellular compounds produced by several isolates of $N$. parvum and $D$. seriata induced various degrees of necrosis and triggered defense gene expression in subcultured calli of Chardonnay. Bénard-Gellon et al. (2015) reported for the first time the expression of defense genes induced by Botryosphaeriaceae protein fractions on grapevine cells. They emphasized the importance of characterizing the functions of these extracellular proteins, in terms of localization and distribution of these secreted metabolites in infected plants, to initiate the in planta investigations of the toxic effects of these proteins. These effects had been previously observed by using callus methods but, by integrating and combining several methods, these important ideas should be validated. For Botryosphaeria dieback, cell suspensions can also be used to unveil plant-pathogen interactions, with emphasis on plant cell defense responses (Stempien et al. 2017). They demonstrated that the rapid response of Vitis cells to secreted Botryosphaeriaceae proteins is in accordance with other studies using artificially inoculated plants as a model.

Methods based on cell cultures are very rapid for screening large numbers of samples under highly controlled conditions, and can also be very useful to help understand the specific interactions between GTD pathogens and grapevines on a molecular level. Nevertheless, they do not sufficiently mimic plant metabolism because factors such as physical restriction of fungal growth, water stress, and other microorganisms that are frequently found in grapevine are not present and not taken into consideration. Once extracellular compounds, excreted metabolites, and defense genes of GTD pathogens are characterized and analyzed, it is important to perform in planta assays in the greenhouse. One of the biggest questions, when using calli and cell culture methods, is to understand to what extent the results obtained can be transferred to the whole plant, even if the molecular responses studied are shown to occur.

Plants and foliar explants. The best methods to comprehend and decipher molecular and physiological effects of compounds that mediate aggressiveness excreted by GTD pathogens probably involve the use of in vitro-obtained plants and foliar explants. Leaf assays with either discs or full leaves can be made to reduce the time for phytotoxin identification at the early screening stage. Abou-Mansour et al. (2015) used this methodology to characterize phytotoxins produced by $N$. parvum and to evaluate their phytotoxicity. They demonstrated that $N$. parvum can produce several phytotoxins that confer a high adaptability and flexibility to this fungus although, as stated by the authors, the putative role of these toxins in disease expression and their mode of action still needs to be clarified. These assays can also be used in early screening for susceptibility of cultivars but, like the cell suspension and calli assays, they do not encompass the plant as a whole. Therefore, in vitro plant assays are the first approach in which the whole plant is integrated and can help to deepen our understanding of the physiological and molecular effect that compounds produced by GTD pathogens have on grapevines. The basal immunity of grapevines or induced relationships with different diseases or elicitors can be studied and discriminated, as described for Botrytis cinerea or Plasmopara viticola (Trotel-Aziz et al. 2006), and can also be used to characterize the detoxification capacity of grapevines toward GTD toxins.

In 2005, Santos et al. (2005) inoculated plantlets by applying $10 \mu \mathrm{l}$ of a spore suspension at their base, for two Portuguese cultivars (Baga and Maria Gomes) and one rootstock (R3309) with P. chlamydospora. They obtained symptoms of senescence close to those described in greenhouse inoculations. The results were in accordance with those of Sparapano et al. (2001), in which plantlets from Italian cultivars infected with $P$. chlamydospora and $P$. minimum showed typical esca foliar symptoms. Plantlets can also be used for histopathological studies, which are currently scarce. By growing in vitro plants and by maintaining them under controlled conditions, upon inoculation, there is a guarantee that only the fungi inoculated will be observed progressing through the plant. Although the progression of the fungi in mature wood will be different compared with that in younger plants, these young 
plantlets allow for studies on young tissue (for example, of the progression of Botryosphaeriaceae fungi causing cankers on young green stems) while in vitro plants, maintained under controlled conditions (in a growth chamber, for example) until they lignify, will allow for studies with more mature tissues. Because one of the main routes for GTD pathogen infection is through pruning wounds, this could unveil new information on how they penetrate and progress inside the plant, allowing further studies on the plant defense responses during the colonization.

\section{THE USE OF IN VIVO NONSTERILE PLANTS}

Laboratory tests are carried out under highly controlled conditions and cannot take into consideration all pathosystem components (detrimental and beneficial). Therefore, the next step is to perform in vivo experiments on inoculated rooted cuttings or grafted plants in the greenhouse. Such trials will allow a study of trunk microbial ecology and interactions within the trunk, interactions on cellular and molecular levels between GTD agents and the host, and tests of new compounds for their ability to limit the impact of GTD pathogens.

Greenhouse methods. The first greenhouse methods to be developed were for Eutypa dieback to demonstrate differences in aggressiveness among isolates of $E$. lata as well as differences in the response of cultivars (Péros and Berger 1994). Péros and Berger (1994) observed that the shoots of rooted cuttings infected with the fungus showed smaller, necrotic leaves, similar to the symptoms found in the vineyard. They also showed that the expression of symptoms depended greatly on the isolate of E. lata used, and that the isolates may differ in their ability to produce toxic compounds which, in turn, depended on the cultivar (Péros and Berger 1994). Cultivars had various responses to inoculation with the same isolate, indicating their susceptibility profile to E. lata. Similarly, Sosnowski et al. (2007) demonstrated, with cuttings artificially infected by E. lata, that the intensity of foliar symptoms appeared to be related to the origin of the isolates, which may reflect variation in aggressiveness. The observation of cultivar tolerance was not in accordance with previous results on mature grapevines of the same cultivar. Consequently, the authors pointed out that one of the possible disadvantages of this model may be the immaturity of the cutting tissues compared with mature grapevines in the field. Greenhouse inoculation tests to assess isolate aggressiveness levels and susceptibility of cultivars to GTD may, therefore, be strongly influenced by stem maturity, whether herbaceous or more or less lignified. This has to be validated by inoculations of young stems or pruning wounded canes in the field. These methods have also been used to characterize molecular interactions between E. lata and grapevines (Camps et al. 2010, 2014) and the effect of water and temperature stress, and for epidemiological studies (Sosnowski et al. 2011). Further studies on the detection of fungal enzymes and host phenolic compounds in the cuttings provided information on the respective importance of several pathogenicity components and host resistance (Péros and Berger 1994). Recently, Moisy et al. (2017) improved a rapid quantitative method, based on real-time PCR, for the assessment of wood colonization by E. lata after inoculation of cuttings in controlled conditions.

A similar model for esca disease with $P$. chlamydospora and $P$. minimum is available. It contains two methods to infect plants (nodal and internodal inoculations) and has been complemented by diverse techniques to better understand defense mechanisms in woody tissues of grapevines. GFP-transformed P. minimum was used to investigate early events in wound colonization (Pierron et al. 2015a), confirming that the niches colonized were in accordance with previous work of Fleurat-Lessard et al. (2010). Pierron et al. (2016) also developed a protocol to study gene expression of grapevine wood infected with $P$. minimum or $P$. chlamydospora where, despite the background noise created by wounding, they observed that woody tissues reacted differently according to the pathogens. Because wounding damage (pruning wounds, mechanical wounds caused by cultural practices, and so on) is considered to be the main gateway for GTD fungi, unveiling which plant responses are to the wound and which are the early responses to infection by pathogens might be a valuable asset to develop new, early diagnostic methodologies. Other tools developed with this model were the monitoring of fungal growth and quantification of DNA copies in the wood, which may be used as a diagnostic test (Pierron et al. 2015a). Finally, for the development of ecofriendly control strategies, a rapid screening in greenhouse conditions could be done even if it probably does not reflect exactly the effect of a chemical or biocontrol agent under vineyard conditions (Mondello et al. 2018). With infected cuttings, the capability of ozone dissolved in water to limit $P$. minimum development was demonstrated (Pierron et al. 2015b) and, more recently, Pierron et al. (2016) used the method to analyze the potential effect of elicitors. The potential efficiency of Pythium oligandrum, a biocontrol agent, was also evaluated with this model (Yacoub et al. 2016).

A method for reproducing necrosis and foliar symptoms with some species associated with Botryosphaeria dieback has been developed. This method permits the characterization of the aggressiveness of Botryosphaeria spp. (Úrbez-Torres and Gubler 2009) by measuring the size of external lesions and also by evaluating the percentage of vines developing foliar symptoms (Reis et al. 2016). Pathogenicity experiments revealed that external lesion sizes and foliar symptoms differed according to the species of fungi inoculated. Plants inoculated with $N$. parvum isolates showed foliar symptom expression that reached $77 \%$, which was always higher than the percentages found for $D$. seriata, which is considered to be a less aggressive pathogen than $N$. parvum (Reis et al. 2016). The plant responses to infection and emergence of foliar symptoms were studied and, among them, some genes such as superoxide dismutase, stilbene synthase, fasciclin-like arabinogalactan, and flavonoids were proposed as potential candidates to be selected as markers for the emergence of the disease. Because the responses of the artificially infected plants show some similarities to those observed in naturally infected plants, including the ability to reproduce foliar symptoms and also the vascular brown stripe, this assay could be applied for future studies. For example, plant defense stimulators to combat Botryosphaeriaceae infection as well as studies aimed at unveiling the relationship between fungi and the appearance of foliar symptoms could be conducted.

The greenhouse methods discussed are appropriate to further comprehend the intricate interactions between GTD-associated fungi and grapevines with molecular, physiological, and epidemiological approaches. Although cuttings and grafted plant methods already take into consideration the grapevine as a whole, these plants are growing under controlled conditions and exclude the reproductive stage, climatic events, and other abiotic or biotic factors to which field-grown grapevines are subjected. Therefore, methods that allow researchers to focus on these parameters under natural conditions (i.e., field-grown grapevines) are also needed.

Pruning wound methods. Pruning wound methods were developed to test cultivar susceptibility and to screen disease control methods, primarily against E. lata (Paillassa 1992) but also against most other GTD fungi (Elena et al. 2015). The most widely used approach worldwide, where the incubation period after pruning wound inoculation is at least 8 months, became the official method for regulation of disease control products in Europe (EPPO 2017). Pruning is one of the most significant cultural practices in viticulture worldwide and the pruning wound model can be considered the best simple model to evaluate pruning wound susceptibility, especially for ecofriendly protectants (Mondello et al. 2018). In light of an increasing number of biocontrol agents tested, 
the classical method, which is performed in the vineyard and with a long incubation period, is now considered to be the most reliable. This method can also avoid false-negative results caused by fastgrowing organisms which may overrun slow-growing pathogens such as Phaeomoniella chlamydospora and Phaeoacremonium minimum (Elena et al. 2015). Elena et al. (2015) demonstrated that the susceptibility of the wounds and subsequent cane colonization may show differential features according to GTD pathogens, suggesting that a new possible global strategy could be optimized by pruning on dates when wound susceptibility to pathogens could be lower. This assay was recently used to validate the new method on detection and quantification $E$. lata and D. seriata complex DNA in pruning wounds (Pouzoulet et al. 2017). A set of primers was developed for detection via $\mathrm{qPCR}$, which allows a sensitive and accurate detection of these pathogens, reinforcing the importance that this model has in aiding the development of new early diagnostic tools.

Grapevines are subjected to a series of cultural practices or environmental conditions during the vegetative growth period which may cause one or more wounds on several organs (e.g., desuckering, climatic events such as hail, or removal of lateral shoots). Because levels of airborne inoculum increase when associated with periods of rainfall and high relative humidity (van Niekerk et al. 2010; Úrbez-Torres et al. 2010), and because the interaction of grapevine and GTD pathogens may be influenced by the amount of inoculum present but also by weather conditions, the last method presented in this review was developed by Spagnolo et al. (2017) to evaluate the period of higher grapevine susceptibility to Botryosphaeriaceae. In this work, the authors demonstrated that the greatest sensitivity to Botryosphaeria dieback agents was during the flowering stage, possibly as a consequence of the high metabolic activity oriented toward the development of the inflorescence. This is correlated with a less-effective plant defense response to the attack. The relationship between grapevine phenological stage, primary metabolism, and GTD pathogen infection could not be studied in the calli and cell suspension methods, and has never been investigated with greenhouse methods. Therefore, this model is adapted to focus on plant-microbe interactions; namely, expression of defense genes and physiological impact on the host under the variable conditions of a vineyard. The aggressiveness of different strains of GTD pathogens as well as the susceptibility of cultivars to them, under specific regional conditions, could be determined. Weather conditions could represent a key factor that modulates the interactions of the plant with GTD pathogens. Trials need to be repeated for at least 3 years to be conclusive.

Advantages and disadvantages. All these methods have advantages and disadvantages, as reported in this discussion but, together, they provide the scientific community with access to a set of tools that will enhance our understanding of the complex interactions between GTD pathogens and grapevines. One of the main advantages is that they can be used in combinations to deepen our knowledge about the interactions of interest. For example, by using the Botryosphaeriaceae model to reproduce foliar symptoms and brown stripe, the metabolites potentially involved in symptom expression could be clarified. Calli and cell suspension methods can help to test the most interesting metabolites and toxins found with the plant model. The combined methods allow a complementary approach such as determining early grapevine responses to wood infection and characterization of microbial equilibrium in grapevines. This may contribute to a better understanding of the defense response against pathogen infection and an understanding of the molecular and physiological impact of GTDs on grapevine, and unveil the interactions between these fungi and the appearance of foliar symptoms. The deeper comprehension of all of these interactions will enable the development of new strategies to diagnose, manage, and control both infection and spread of GTDs. Each of these strategies can be tested and perfected thanks to these simple methods.

\section{ACKNOWLEDGMENTS}

We thank A. Philipps, a native English speaker and researcher at the University Nova of Lisboa, for revising the English of this article.

\section{LITERATURE CITED}

Abou-Mansour, E., Couché, E., and Tabacchi, R. 2004. Do fungal naphthalenones have a role in the development of esca symptoms? Phytopathol. Mediterr. 43:75-82.

Abou-Mansour, E., Débieux, J., Ramírez-Suero, M., Bénard-Gellon, M., Magnin-Robert, M., Spagnolo, A., Chong, J., Farine, S., Bertsch, C., L'Haridon, F., Serrano, M., Fontaine, F., Rego, C., and Larignon, P. 2015. Phytotoxic metabolites from Neofusicoccum parvum, a pathogen of Botryosphaeria dieback of grapevine. Phytochemistry 115:207-215.

Andolfi, A., Basso, S., Giambra, S., Conigliaro, G., Lo Piccolo, S., Alves, A., and Burruano, S. 2016. Lasiolactols A and B produced by the grapevine fungal pathogen Lasiodiplodia mediterranea. Chem. Biodivers. 13: 395-402.

Andolfi, A., Mugnai, L., Luque, J., Surico, G., Cimmino, A., and Evidente, A. 2011. Phytotoxins produced by fungi associated with grapevine trunk diseases. Toxins (Basel) 3:1569-1605.

Ayres, M., Sosnowski, M., and Wicks, T. 2011. A rapid technique for evaluating treatments for Eutypa dieback control. Wine Vitic. J. November/ December 2011:50-53.

Behnke, M. 1979. Selection of potato callus for resistance to culture filtrates of Phytophthora infestans and regeneration of resistant plants. Theor. Appl. Genet. 55:69-71.

Bellée, A., Comont, G., Nivault, A., Abou-Mansour, E., Coppin, C., Dufour, M. C., and Corio-Costet, M. F. 2017. Life traits of four Botryosphaeraciae species and molecular response of different grapevine cultivars or hybrids. Plant Pathol. 66:763-776.

Bénard-Gellon, M., Farine, S., Goddard M. L., Schmitt, M., Stempien, E., Pensec, F., Laloue, H., Mazet-Kiedder, F., Fontaine, F., Larignon, P., Chong, J., and Bertsch, C. 2015. Toxicity of extracellular proteins from Diplodia seriata and Neofusicoccum parvum involved in grapevine Botryosphaeria dieback. Protoplasma 252:679-687.

Bertsch, C., Ramírez-Suero, M., Magnin-Robert, M., Larignon, P., Chong, J., Abou-Mansour, E., Spagnolo, A., Clément, C., and Fontaine, F. 2013. Grapevine trunk diseases: Complex and still poorly understood. Plant Pathol. 62:243-265.

Bruno, G., and Sparapano, L. 2006. Effects of three esca-associated fungi on Vitis vinifera L.: Characterization of secondary metabolites in culture media and host responses to the pathogens in calli. Physiol. Mol. Plant Pathol. 69: 209-223.

Camps, C., Kappel, C., Lecomte, P., Léon, C., Coutos-Thévenot, P., Delrot, S., and Gomès, E. 2014. Identification of grapevine marker genes for early, non-destructive Eutypa lata infection diagnosis. Plant Pathol. 63:323-333.

Camps, C., Kappel, C., Lecomte, P., Léon, C., Gomès, E., Coutos-Thévenot, P., and Delrot, S. 2010. A transcriptomic study of grapevine (Vitis vinifera cv. Cabernet-Sauvignon) interaction with the vascular ascomycete fungus Eutypa lata. J. Exp. Bot. 61:1719-1737.

Carter, M. V. 1991. The Status of Eutypa lata as a Pathogen. Monogr. Phytopathol. Pap. 32. Commonwealth Agricultural Bureau, International Mycological Institute, Wallingford, Surrey, U.K.

Carter, M. V., and Moller, W. J. 1971. The quantity of inoculum required to infect apricot and other Prunus species with Eutypa armeniacae. Aust. J. Exp. Agric. Anim. Husb. 11:684-686.

Chapuis, L. 1995. L'Eutypiose de la vigne: Contribution à l'étude des relations hôte-parasite. Ph.D. thesis, University of Bordeaux II, France.

Chapuis, L., Richard, L., and Dubos, B. 1998. Variation in susceptibility of grapevine pruning wound to infection by Eutypa lata in south-western France. Plant Pathol. 47:463-472.

Cimmino, A., Cinelli, T., Masi, M., Reveglia, P., Araujo da Silva, M., Mugnai, L., Michereff, S. J., Surico, G., and Evidente, A. 2017. Phytotoxic lipophilic metabolites produced by grapevine strains of Lasiodiplodia species in Brazil. J. Agric. Food Chem. 65:1102-1107.

Cloete, M., Fischer, M., Mostert, L., and Halleen, F. 2015. Hymenochaetales associated with esca-related wood rots on grapevine with a special emphasis on the status of esca in South African vineyards. Phytopathol. Mediterr. 54: 299-312.

De la Fuente, M., Fontaine, F., Gramaje, D., Armengol, J., Smart, R., Nagy, Z. A., Borgo, M., Rego, C., and Corio-Costet, M. 2016. 1st ed. OIV Publications, Paris, France.

Elena, G., Sosnowski, M. R., Ayres, M. R., Lecomte, P., Benetreau, C., Garcia-Figueres, F., and Luque, J. 2015. Effect of the inoculum dose of 
three grapevine trunk pathogens on infection of artificially inoculated pruning wounds. Phytopathol. Mediterr. 54:345-354.

EPPO. 2017. Standard PP 1/303 (1) Eutypa lata on grapevine. Bull. OEPP/ EPPO Bull. 47:333-336.

Evidente, A., Superchi, S., Cimmino, A., Mazzeo, G., Mugnai, L., Rubiales, D., Andolfi, A., and Villegas-Fernandez, A. M. 2011. Regiolone and isosclerone, two enantiomeric phytotoxic naphthalenone pentaketides: Computational assignment of absolute configuration and its relationship with phytotoxic activity. Eur. J. Org. Chem. 2011:5564-5570.

Ferreira, R. B., Monteiro, S. S., Picarra-Pereira, M. A., and Teixeira, A. R. 2004. Engineering grapevine for increased resistance to fungal pathogens without compromising wine stability. Trends Biotechnol. 22:168-173.

Fischer, J., Compant, S., Pierron, R. J. G., Gorfer, M., Jacques, A., Thines, E., and Berger, H. 2016. Differing alterations of two esca associated fungi, Phaeoacremonium aleophilum and Phaeomoniella chlamydospora on transcriptomic level, to co-cultured Vitis vinifera L. calli. PLoS One 11: e0163344.

Fleurat-Lessard, P., Luini, E., Berjeaud, J. M., and Roblin, G. 2010. Diagnosis of grapevine esca disease by immunological detection of Phaeomoniella chlamydospora. Aust. J. Grape Wine Res. 16:455-463.

Gramaje, D., Úrbez-Torres, J. R., and Sosnowski, M. 2018. Managing grapevine trunk diseases with respect to etiology and epidemiology: Current strategies and future prospects. Plant Dis. 102:12-39.

Gruau, C., Trotel-Aziz, P., Villaume, S., Rabenoelina, F., Clément, C., Baillieul, F., and Aziz, A. 2015. Pseudomonas fluorescens PTA-CT2 triggers local and systemic immune response against Botrytis cinerea in grapevine. Mol. Plant-Microbe Interact. 28:1117-1129.

Jung, V., Valtaud, C., Hevin, C., Limiñana, J. M., Gomès, E., Ferrari, G., and Lecomte, P. 2010. Development of rapid bioassays for the screening of plant grapevine material with regard to Eutypa dieback. Phytopathol. Mediterr. 49:124-125.

Larignon, P., and Dubos, B. 1997. Fungi associated with Esca disease in grapevine. Eur. J. Plant Pathol. 103:147-157.

Larignon, P., Fulchic, R., Cere, L., and Dubos, B. 2001. Observation on black dead arm in French vineyards. Phytopathol. Mediterr. 40:S336-S342.

Larignon, P., Spagnolo, A., Bertsch, C., and Fontaine, F. 2015. First report of young grapevine decline caused by Neofusicoccum parvum in France. Plant Dis. 99:1859.

Laveau, C., Letouze, A., Louvet, G., Bastien, S., and Guérin-Dubrana, L. 2009. Differential aggressiveness of fungi implicated in esca and associated diseases of grapevine in France. Phytopathol. Mediterr. 48:32-46.

Lecomte, P., and Bailey, D. J. 2011. Studies on the infestation by Eutypa lata of grapevine spring wounds. Vitis 50:35-41.

Lecomte, P., Darrieutort, G., Liminana, J.-M., Comont, G., Muruamendiaraz, A., Legorburu, F.-J., Choueiri, E., Jreijiri, F., El Amil, R., and Fermaud, M. 2012. New insights into esca of grapevine: The development of foliar symptoms and their association with xylem discoloration. Plant Dis. 96: 924-934

Lecomte, P., Laveau, E., Giry Laterriere, S., Dewasme, C., and Clerjeau, M. 2003. Optimisation of pruning wound protection for the control of Eutypa dieback of grapevine in France. "Integrated Protection and Production in Viticulture". IOBC WPRS Bull. 26:95-96.

Martos, S., Andolfi, A., Luque, J., Mugnai, L., Surico, G., and Evidente, A. 2008. Production of phytotoxic metabolites by five species of Botryosphaeriaceae causing decline on grapevines, with special interest in the species Neofusicoccum luteum and N. parvum. Eur. J. Plant Pathol. 121: 451-461.

Mohammadi, H., Gramaje, D., Banihashemi, Z., and Armengol, J. 2013. Characterization of Diplodia seriata and Neofusicoccum parvum associated with grapevine decline in Iran. J. Agric. Sci. Technol. 15:603-616.

Moisy, C., Berger, G., Flutre, T., Le Cunff, L., and Péros, J.-P. 2017. Quantitative assessment of grapevine wood colonization by the dieback fungus Eutypa lata. J. Fungi 3:21.

Moller, W. J., and Kasimatis, A. N. 1980. Protection of grapevine pruning wounds from Eutypa dieback. Plant Dis. 64:278-280.

Mondello, V., Songy, A., Battiston, E., Pinto, C., Coppin, C., Trotel-Aziz, P., Clément, C., Mugnai, L., and Fontaine, F. 2018. Grapevine trunk diseases: A review of fifteen years of trials for their control with chemicals and biocontrol agents. Plant Dis. 102:1189-1217.

Mugnai, L., Graniti, A., and Surico, G. 1999. Esca (Black measles) and brown wood streaking: Two old and elusive diseases of grapevines. Plant Dis. 83: 404-418.

Mur, G. 1979. Essais d'infection de la vigne par le champignon Eutypa armeniacae. Prog. Agric. Vitic. 96:334-337.

Mur, G. 1988. Les maladies du bois de la vigne. Prog. Agric. Vitic. 105: 575-577.

Murolo, S., and Romanazzi, G. 2014. Effects of grapevine cultivar, rootstock and clone on esca disease. Australas. Plant Pathol. 43:215-221.
Paillassa, E. 1992. L'eutypiose de la vigne (Eutypa lata (Pers.:Fr) Tul.): Aspects épidémiologiques-Application à la mise au point d'une méthode d'évaluation des fongicides in vivo. Ph.D. thesis, Université de Bordeaux II, France.

Péros, J.-P., and Berger, G. 1994. A rapid method to assess the aggressiveness of Eutypa lata isolates and the susceptibility of grapevine cultivar to Eutypa dieback. Agronomie 14:515-523.

Péros, J. P., and Berger, G. 1999. Diversity within natural progenies of grapevine dieback fungus Eutypa lata. Curr. Genet. 36:301-309.

Perrin, M., Gertz, C., and Masson, J. E. 2004. High efficiency initiation of regenerable embryogenic callus from anther filaments of 19-grapevine genotypes grown worldwide. Plant Sci. 167:1343-1349.

Petzoldt, C. H., Moller, W. J., and Sall, M. A. 1981. Eutypa dieback of grapevine: Seasonal differences in infection and duration in susceptibility of pruning wounds. Phytopathology 71:540-543.

Pierron, R. J. G., Gorfer, M., Berger, H., Jacques, A., Sessitsch, A., Strauss, J., and Compant, S. 2015a. Deciphering the niches of colonisation of Vitis vinifera L. by the esca-associated fungus Phaeoacremonium aleophilum using a gfp marked strain and cutting systems. PLoS One 10:e0126851.

Pierron, R. J. G., Pagès, M., Couderc, C., Compant, S., Jacques, A., and Violleau, F. 2015b. In vitro and in planta fungicide properties of ozonated water against the esca-associated fungi Phaeoacremonium aleophilum. Sci. Hortic. (Amsterdam, Neth.) 189:184-191.

Pierron, R. J. G., Pouzoulet, J., Couderc, C., Judic, E., Compant, S., and Jacques, A. 2016. Variations in early response of grapevine wood depending on wound and inoculation combinations with Phaeoacremonium aleophilum and Phaeomoniella chlamydospora. Front. Plant Sci. 7:268.

Pijut, P. M., Domir, S. C., Lineberger, R. D., and Schreiber, L. R. 1990. Use of culture filtrates of Ceratocystis ulmi as a bioassay to screen for disease tolerant Ulmus americana. Plant Sci. 70:191-196.

Pouzoulet, J., Mailhac, N., Couderc, C., Besson, X., Daydé, J., Lummerzheim, M., and Jacques, A. 2013. A method to detect and quantify Phaeomoniella chlamydospora and Phaeoacremonium aleophilum DNA in grapevine-wood samples. Appl. Microbiol. Biotechnol. 97:10163-10175.

Pouzoulet, J., Rolshausen, P., Schiavon, M., Sebastiaan, B., Travadon, R., Lawrence, D. P., Baumgartner, K., Ashworth, V. E., Comont, G., Corio-Costet, M. F., Pierron, R., Besson, X., and Jacques, A. 2017. A method to detect and quantify Eutypa lata and Diplodia seriata-complex DNA in grapevine pruning wounds. Plant Dis. 101:1470-1480.

Ramírez-Suero, M., Bénard-Gellon, M., Chong, J., Laloue, H., Stempien, E., Abou-Mansour, E., Fontaine, F., Larignon, P., Mazet-Kieffer, F., Farine, S., and Bertsch, C. 2014. Extracellular compounds produced by fungi associated with Botryosphaeria dieback induce differential defense gene expression patterns and necrosis in Vitis vinifera cv. Chardonnay cells. Protoplasma 251:1417-1426.

Ramos, D. E., Moller, W. J., and English, H. 1975. Susceptibility of apricot tree pruning wounds to infection by Eutypa armeniacae. Phytopathology 65:1359-1364.

Reis, P., Magnin-Robert, M., Nascimento, T., Spagnolo, A., Abou-Mansour, E., Fioretti, C., Clément, C., Rego, C., and Fontaine, F. 2016. Reproducing Botryosphaeria dieback foliar symptoms in a simple model system. Plant Dis. 100:1071-1079.

Rolshausen, P., Úrbez-Torres, J. R., Rooney-Latham, S., Eskalen, A., Smith, R. J., and Gubler, W. D. 2010. Evaluation of pruning wound susceptibility and protection against fungi associated with grapevine trunk diseases. Am. J. Enol. Vitic. 61:113-119.

Santos, C., Fragoeiro, S., and Phillips, A. 2005. Physiological response of grapevine cultivars and a rootstock to infection with Phaeoacremonium and Phaeomoniella isolates: An in vitro approach using plants and calluses. Sci. Hortic. (Amsterdam, Neth.) 103:187-198.

Smith, L. R., Mahoney, N., and Molyneux, R. J. 2003. Synthesis and structurephytotoxicity relationships of acetylenic phenols and chromene metabolites, and their analogues, from the grapevine pathogen Eutypa lata. J. Nat. Prod. 66:169-176.

Sosnowski, M., Creaser, M. L., Wicks, T. J., Lardner, R., and Scott, E. S. 2008. Protection of grapevine using wounds from infection by Eutypa lata. Aust. J. Grape Wine Res. 14:134-142.

Sosnowski, M., Luque, J., Loschiavo, A. P., Martos, S., Garcia-Figueres, F., Wicks, T. and Scott, E. S. 2011. Studies on the effect of water and temperature stress on grapevines inoculated with Eutypa lata. Phytopathol. Mediterr. 50:127-138.

Sosnowski, M. R., Lardner, R., Wicks, T. J., and Scott, E. S. 2007. The influence of grapevine cultivar and isolate of Eutypa lata on wood and foliar symptoms. Plant Dis. 91:924-931.

Spagnolo, A., Mondello, V., Larignon, P., Villaume, S., Rabenoelina, F., Clément, C., and Fontaine, F. 2017. Defense responses in grapevine (cv. Mourvèdre) after inoculation with the Botryosphaeria dieback pathogens 
Neofusicoccum parvum and Diplodia seriata and their relationship with flowering. Int. J. Mol. Sci. 18:393.

Sparapano, L., De Leonardis, S., Campanella, A., and Bruno, G. 2001. Interaction between esca-associated fungi, grapevine calli and micropropagated shoot cultures of grapevine. Phytopathol. Mediterr. 40:423-428.

Stempien, E., Goddard, M. L., Leva, Y., Bénard-Gellon, M., Laloue, H., Farine, S., Kieffer-Mazet, F., Tarnus, C., Bertsch, C., and Chong, J. 2017. Secreted proteins produced by fungi associated with Botryosphaeria dieback trigger distinct defense responses in Vitis vinifera and Vitis rupestris cells. Protoplasma 255:613-628.

Taylor, A., Hardy, G. E. St. J., Wood, P., and Burgess, T. 2005. Identification and pathogenicity of Botryosphaeria species associated with grapevine decline in Western Australia. Australas. Plant Pathol. 34:187-195.

Trotel-Aziz, P., Abou-Mansour, E., Courteaux, B., Rabenoelina, F., Clément, C., Fontaine, F. and Aziz, A. 2019. Bacillus subtilis PTA-271 counteracts Botryosphaeria dieback in grapevine, triggering immune responses and detoxification of fungal phytotoxins. Front. Plant Sci. 10:25.

Trotel-Aziz, P., Couderchet, M., Vernet, G., and Aziz, A. 2006. Chitosan stimulates defense reactions in grapevine leaves and inhibits development of Botrytis cinerea. Eur. J. Plant Pathol. 114:405-413.

Trouillas, F. P., Úrbez-Torres, J. R., and Gubler, W. D. 2010. Diversity of diatrypaceous fungi associated with grapevine canker diseases in California. Mycologia 102:319-336.

Úrbez-Torres, J. R. 2011. The status of Botryosphaeriaceae species infecting grapevines. Phytopathol. Mediterr. 50:S5-S45.
Úrbez-Torres, J. R., Battany, M., Bettiga, L. J., Gispert, C., McGourty, G., Roncoroni, J., Smith, R. J., Verdegaal, P., and Gubler, W. D. 2010. Botryosphaeriaceae species spore-trapping studies in California vineyards. Plant Dis. 94:717-724.

Úrbez-Torres, J. R., and Gubler, W. D. 2009. Pathogenicity of Botryosphaeriaceae species isolated from grapevine cankers in California. Plant Dis. 93: $584-592$

van Niekerk, J. M., Bester, W., Halleen, F., Crous, P. W., and Fourie, P. H. 2011. The distribution and symptomatology of grapevine trunk disease pathogens are influenced by climate. Phytopathol. Mediterr. 50: S98-S111.

van Niekerk, J. M., Calitz, F. J., Halleen, F., and Fourie, P. H. 2010. Temporal spore dispersal patterns of grapevine trunk pathogens in South Africa. Eur. J. Plant Pathol. 127:375-390.

Wagschal, I., Christen, D., and Défago, G. 2007. Effect of esca and Eutypa dieback toxins on the regulation of grapevine defense responses. Phytopathol. Mediterr. 46:113-114.

Wielgoss, A., and Kortekamp, A. 2006. Comparison of PR1 expression in grapevine cultures after inoculation with a host- and a non-host pathogen. Vitis 45:9-13.

Yacoub, A., Gerbore, J., Magnin, N., Chambon, P., Dufour, M. C., Corio-Costet, M. F., Guyoneaud, R., and Rey, P. 2016. Ability of Pythium oligandrum strains to protect Vitis vinifera $\mathrm{L}$., by inducing plant resistance against Phaeomoniella chlamydospora, a pathogen involved in Esca, by inducing plant resistance. Biol. Control 92:7-16. 